Article

\title{
Blue-Green Infrastructure (BGI) in Dense Urban Watersheds. The Case of the Medrano Stream Basin (MSB) in Buenos Aires
}

\author{
Daniel Kozak ${ }^{1, *}$, Hayley Henderson ${ }^{2}$, Alejandro de Castro Mazarro ${ }^{3}\left[\right.$, Demián Rotbart ${ }^{4}{ }^{(}$and \\ Rodolfo Aradas 5 \\ 1 Centro de Estudios Urbanos y Regionales CEUR-CONICET/Centro de Investigación Hábitat y Energía, \\ Facultad de Arquitectura, Diseño y Urbanismo, Universidad de Buenos Aires, Saavedra 15, Ciudad \\ Autónoma de Buenos Aires 1083, Argentina \\ 2 Centro de Estudios Urbanos y Regionales CEUR-CONICET/Crawford School of Public Policy, The \\ Australian National University, JG Crawford Building, 132 Lennox Crossing, Canberra ACT 2600, Australia; \\ hayley.henderson@anu.edu.au \\ 3 Leibniz Institute of Ecological Urban and Regional Development, Weberplatz 1, 01217 Dresden, Germany; \\ a.decastro@ioer.de \\ 4 Facultad de Arquitectura, Diseño y Urbanismo, Universidad de Buenos Aires, Ciudad Universitaria, Ciudad \\ Autónoma de Buenos Aires 1428, Argentina; demian.rotbart@fadu.uba.ar \\ 5 Facultad de Ingeniería, Universidad de Buenos Aires, Av. Paseo Colón 850, Ciudad Autónoma de Buenos \\ Aires 1063, Argentina; raradas@fi.uba.ar \\ * Correspondence: daniel.kozak@conicet.gov.ar
}

Received: 31 December 2019; Accepted: 1 March 2020; Published: 11 March 2020

check for updates

\begin{abstract}
Conventional urban drainage approaches have historically focused on the volume of stormwater to be displaced with the aim of moving it as fast and as far as possible from the city. They have also been negligent regarding water quality and the inherent value of watercourses to distinct forms of life in cities, from maintaining biodiversity to providing recreational space for residents. Contemporary responses to these issues point to a paradigm change: They seek to replicate the natural mechanisms of absorption and retention, with the aim of addressing pluvial drainage needs closer to the site of origin. This article aims to explore the extent to which such an approach could be accommodated in one dense and highly impervious setting in the Global South. Specifically, it compares urban morphology, land value, hydraulic performance, and politico-institutional conditions of grey and Blue-Green Infrastructure (BGI) scenarios in Buenos Aires, Argentina. The findings suggest that even in very dense and impervious urban basins it is possible to implement BGI with a significant effect in achieving urban-sustainability goals. Furthermore, the results demonstrate that it is possible to deculvert watercourses in line with Compact City principles through the development of hybrid BGI/grey-infrastructure systems.
\end{abstract}

Keywords: Blue-Green Infrastructure; sustainable drainage systems; nature-based solutions

\section{Introduction}

There is a growing global consensus about the shortcomings of traditional hard-engineering solutions to tackle urban drainage [1-10]. Conventional hydraulic engineering-from now on grey infrastructure - has historically concentrated its efforts on the volume of stormwater to be displaced, with the aim of moving it as fast and as far as possible from the city, while it has been negligent regarding the quality of water and its capacity to enhance urban life. Grey infrastructure technologies have not only increased contamination in the culverted watercourses, decreased the replenishment of aquifers 
and neglected the inherent potential of rivers and streams to provide amenity and environmental services [1-4,7], but they also exacerbate flooding downstream, due to the acceleration of drainage time and often in the upper basins as a result of obstructions in the culverts [3,7]. Furthermore, the reduction of natural hydrologic functions, such as interception, evapotranspiration, retention, and infiltration of rainwater, has resulted in the increase of the volume of stormwater, which in turn "increases the peak, rate of flow, and frequency of flooding" [4] (p. 1112).

Contemporary responses to these issues point to a change of paradigm in the design and management of urban drainage. They seek to replicate the natural mechanisms of absorption and retention, with the aim of solving pluvial drainage closer to the site of origin. They often include projects of "deculverting" or "daylighting" and the renaturalization of watercourses to different degrees. Basically, and adopting the terminology of a Source Pathway Receptor model to interpret the urban risk of flooding [5], the focus of contemporary approaches is on managing runoff at the source rather than the traditional approach of increasing the conveyance capacity of the transmission system.

According to Fletcher et al., the planning of drainage in cities and of the urban water cycle, in general, has undergone a significant change in recent decades [6] (p. 525). It has shifted from very limited approaches with the sole purpose of flood reduction to broader approaches in which multiple objectives drive the design and decision-making process. There is a quest for innovative techniques that aim to capture, retain and reuse rainwater within the watershed, closer to the source of the runoff [6] (p. 527), instead of constructing massive drainage structures [7] (p. 13). The main challenge is the development of "watershed-wide stormwater quality management plans to meet the dual objectives of flood prevention and water quality control" [6] (p. 527).

The relatively recent concept of Blue-Green Infrastructure (BGI) refers to the recognition of green space and water's innate capacities—and the ecosystems in which they are immersed-to produce environmental benefits, as well as to improve the quality of life in cities. The English term BGI first appeared in the 2000s [8] and at around the same time that the concept of Trame Verte et Bleue emerged in France, as an integrated conservation policy focused on the existence of biodiversity corridors along watercourses and throughout cities [9]. Some BGI components include green corridors, parks, nature reserves, rivers, streams, lakes, lagoons, open green reservoirs, bioretention basins and floodable parks. They range from non-specialized traditional urban features, such as green boulevards and common gardens, to more advanced-but still low-tech-components, such as "vegetated depressions engineered to capture and filter stormwater" [10] (pp. 2-3). They can be open to the public or have restricted access and can be built on public or private land. One of their salient characteristics is that they provide ecosystem services, such as the reduction of the Heat Island effect and temperature regulation in general; improvements in air quality through the use of the phytoremediation capacity of urban vegetation; carbon sequestration; noise reduction; restoration or establishment of biodiversity corridors; and our main focus in this article-greater control in the management of stormwater runoff and water quality. Additionally, the superposition of BGI on an existing grey infrastructure network-as in this case study-increases the resilience of the overall system by producing a redundancy effect between both networks. Redundancy within systems helps to provide backup options to infrastructure when shocks occur, and has been proposed as the main resilience strategy in recent resilience studies [11].

There is a wide variety of terms that accounts for this shift from grey to blue-green infrastructure, which is suggestive of the dynamism that these debates presently have. Fletcher et al. analyse "the evolution and application of terminology surrounding urban drainage" and identify some of the main concepts in this new bibliography [6]. One of the most common is "Water Sensitive Urban Design" (WSUD), which emphasizes the idea of "adding value while minimising drainage infrastructure development costs" [12], as one of the five WSUD points included in Urban stormwater: best practice environmental management guidelines. Other terms that circulate widely that we can highlight are: "Integrated urban water management" (IUWM), "Stormwater control measures" (SCMs), "Stormwater quality improvement devices" (SQIDs), and primarily "Sustainable urban drainage systems" (SUDS), coined in the late 1990s by Scottish Water and currently the predominant term in the UK, continental 
Europe and most of the world, including Latin America. Inherent in the idea of SUDS lies the concept of the "sustainable drainage triangle", initially established by D'Arcy [13] and currently widely disseminated as the virtuous conjunction of three dimensions: (1) Quantity, (2) quality and (3) amenity/biodiversity. The concept of SUDS is understood to be included in the umbrella category BGI, as well as the practice of deculverting or daylighting piped and buried watercourses [14,15], which is an emblematic example of a procedure that can produce synergies between environmental, public-space and socio-economic goals, as has been shown in cases, such as Seoul's Cheonggyecheon [16,17], Yonkers' Saw Mill river [18] and Singapore's Bishang-Ang [19], among several others.

One of the main challenges of implementing BGI solutions to tackle urban drainage in numerous contemporary urban regions in the world, and particularly in the Global South, is the high level of impermeabilization of dense urban environments. Thus, the challenge is how to create more absorbent surfaces and increase water retention capacity in cities-tasks that require space-while preserving or increasing urban density along with its positive attributes [20-25]. In this regard, there is a potential tension between BGI's agenda and that of the Compact City.

The main aim of this article is to examine the extent to which a BGI approach could be accommodated in one dense and highly impervious setting, using a case study of the Medrano Stream Basin (MSB) in Buenos Aires, Argentina. The MSB covers an area of 5567 ha; $32 \%$ of this area lies within the Autonomous City of Buenos Aires (ACBA), and the remaining $68 \%$ is divided between three municipalities in the Province of Buenos Aires: San Martín, Tres de Febrero and Vicente López (Figure 1). It is the fourth largest water basin of the Metropolitan Area of Buenos Aires (MABA) (Figure 2), and has a residential population of 514,642 inhabitants and a 925hab/ha density (Figure 3). It is mostly a floodplain with extensive water penetration from the de la Plata River (Figure 4). Its average impermeabilization level is $74 \%$, with predominance of the $51-75 \%$ and $76-100 \%$ ranges (Figure 5). Furthermore, there are significant levels of impermeabilization located in upstream areas of the main watercourse (in San Martin and Tres de Febrero), as well as in the upstream part of the right bank tributaries in the City of Buenos Aires, which impose a significant hydraulic burden to the trunk conveyance system.

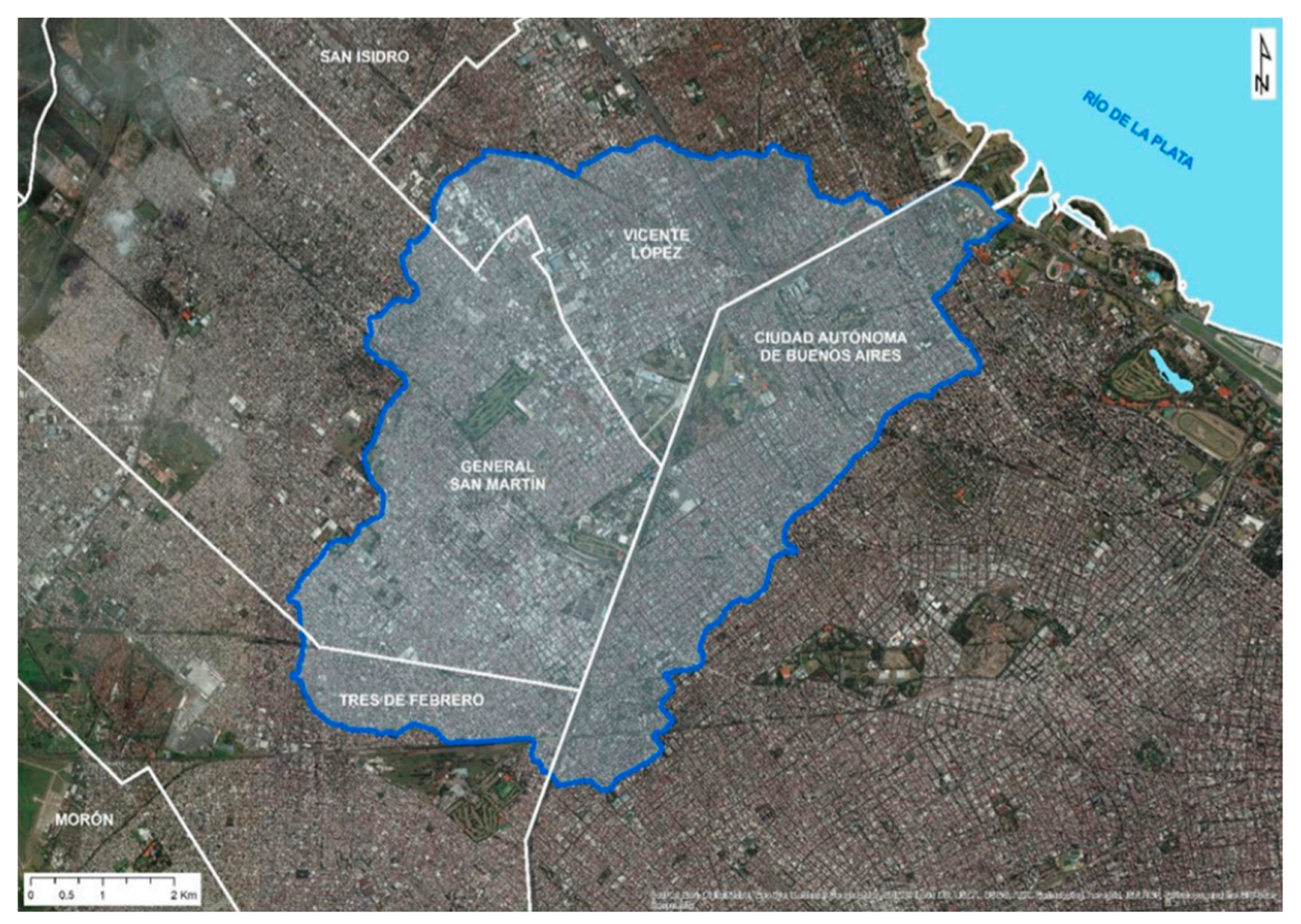

Figure 1. Medrano Stream Basin (MSB) politico-administrative divisions. Source: UDMP-MSB [26]. 


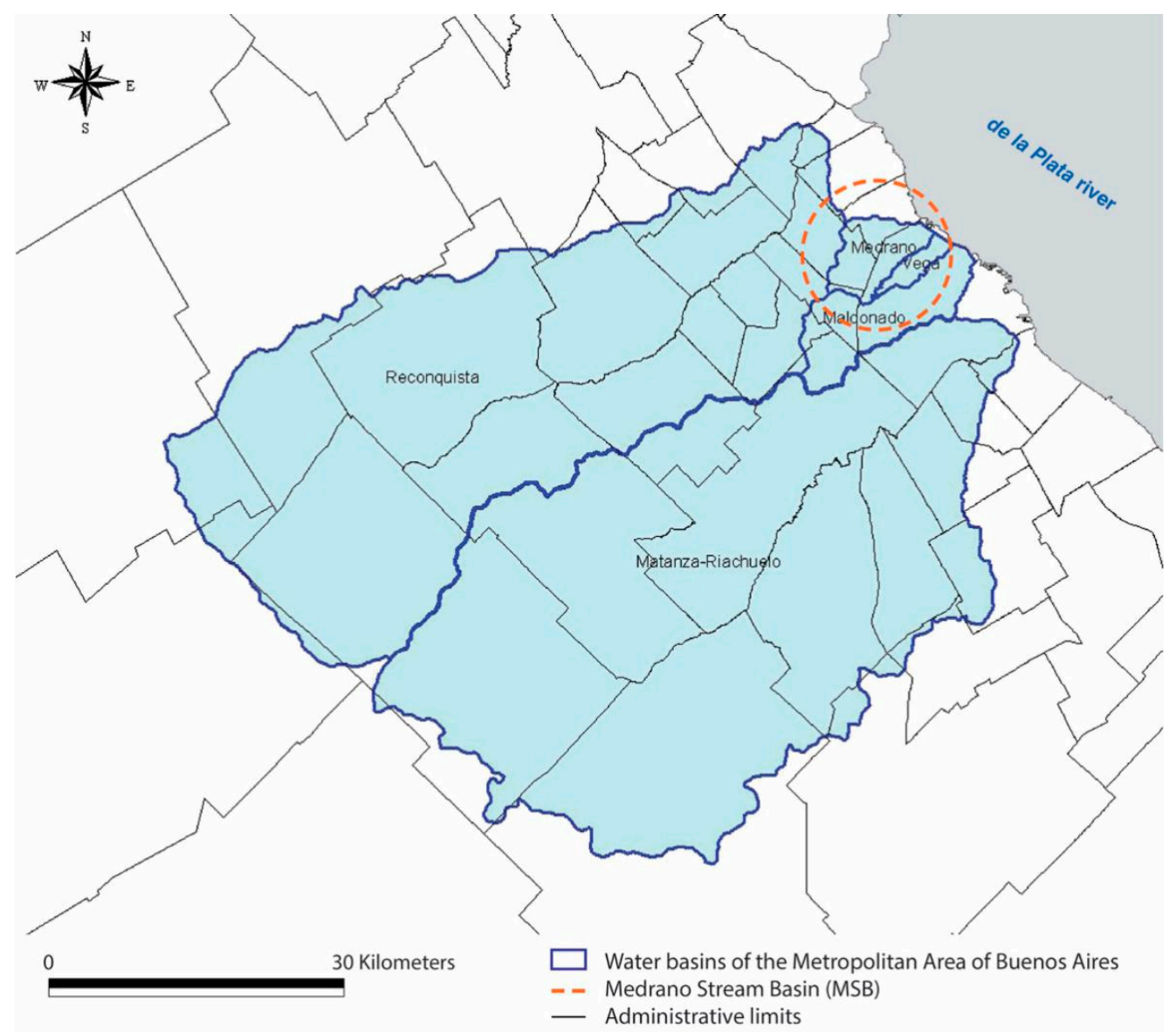

Figure 2. Water basins in the Metropolitan Area of Buenos Aires.

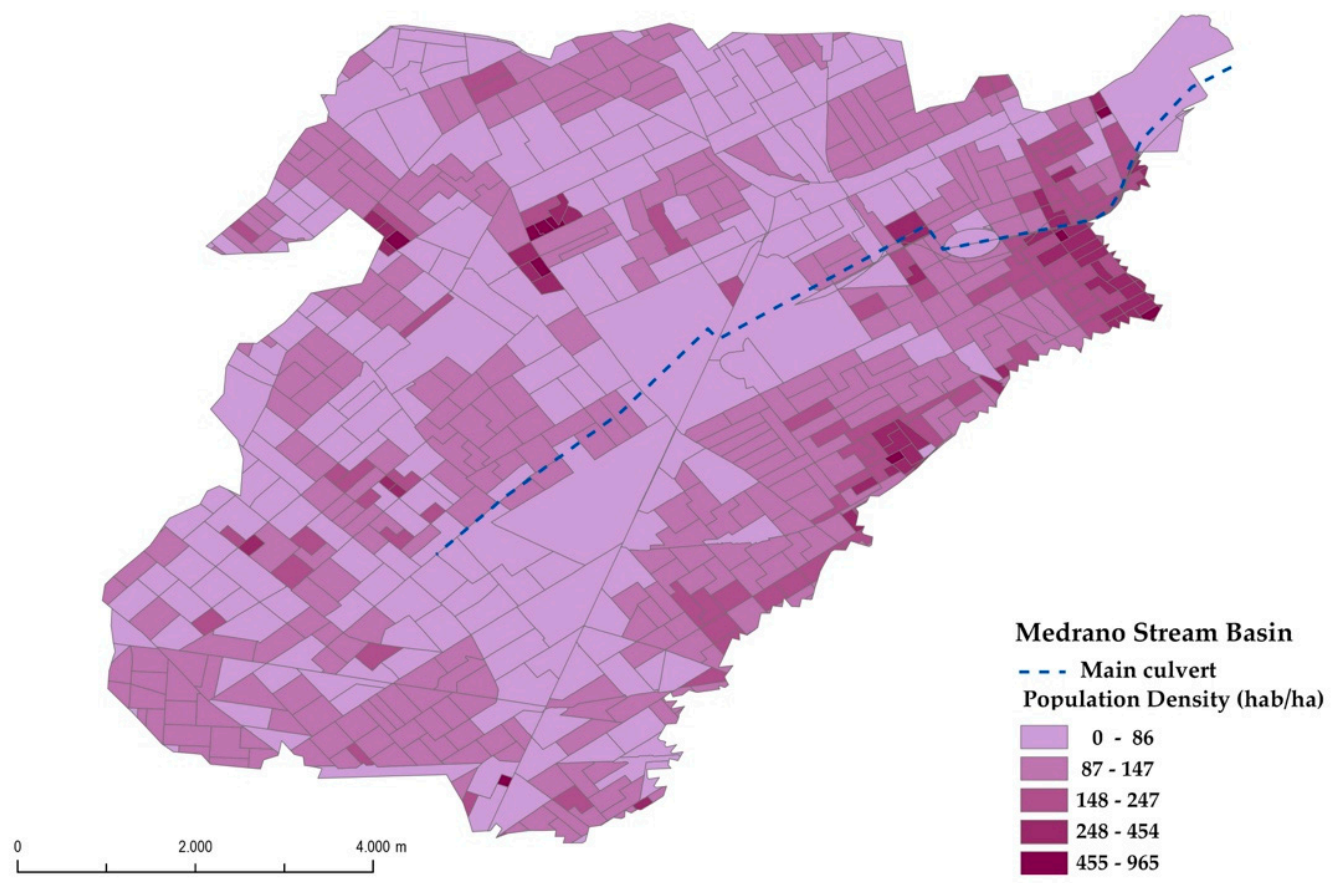

Figure 3. Medrano Stream Basin (MSB) population density. Source: Own elaboration based on data provided by the "2010 National Census of Population, Households and Housing”, INDEC, 2010. 


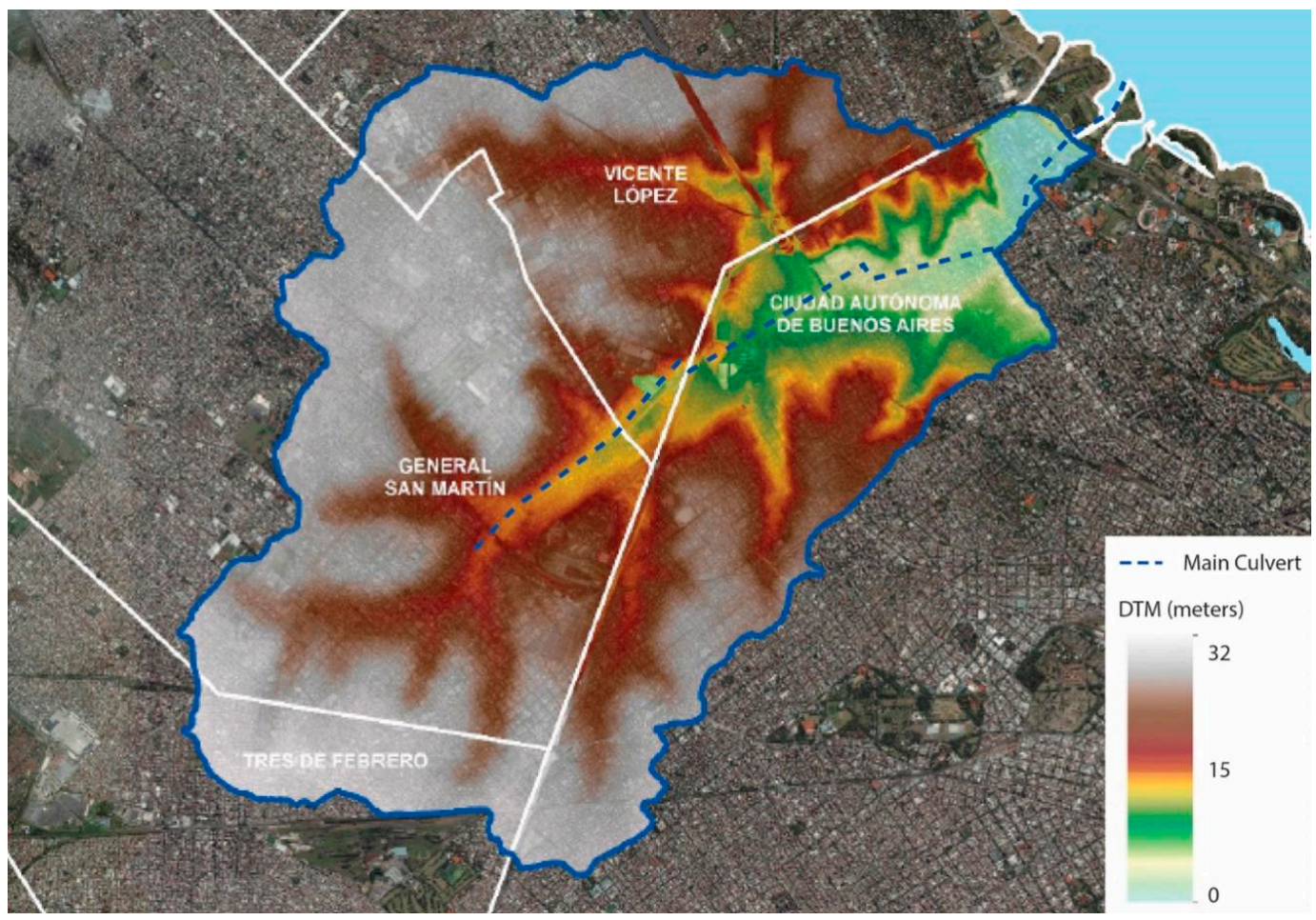

Figure 4. MSB topography based on a Digital Terrain Model (DTM). Source: Translated and adapted from UDMP-MSB [26].

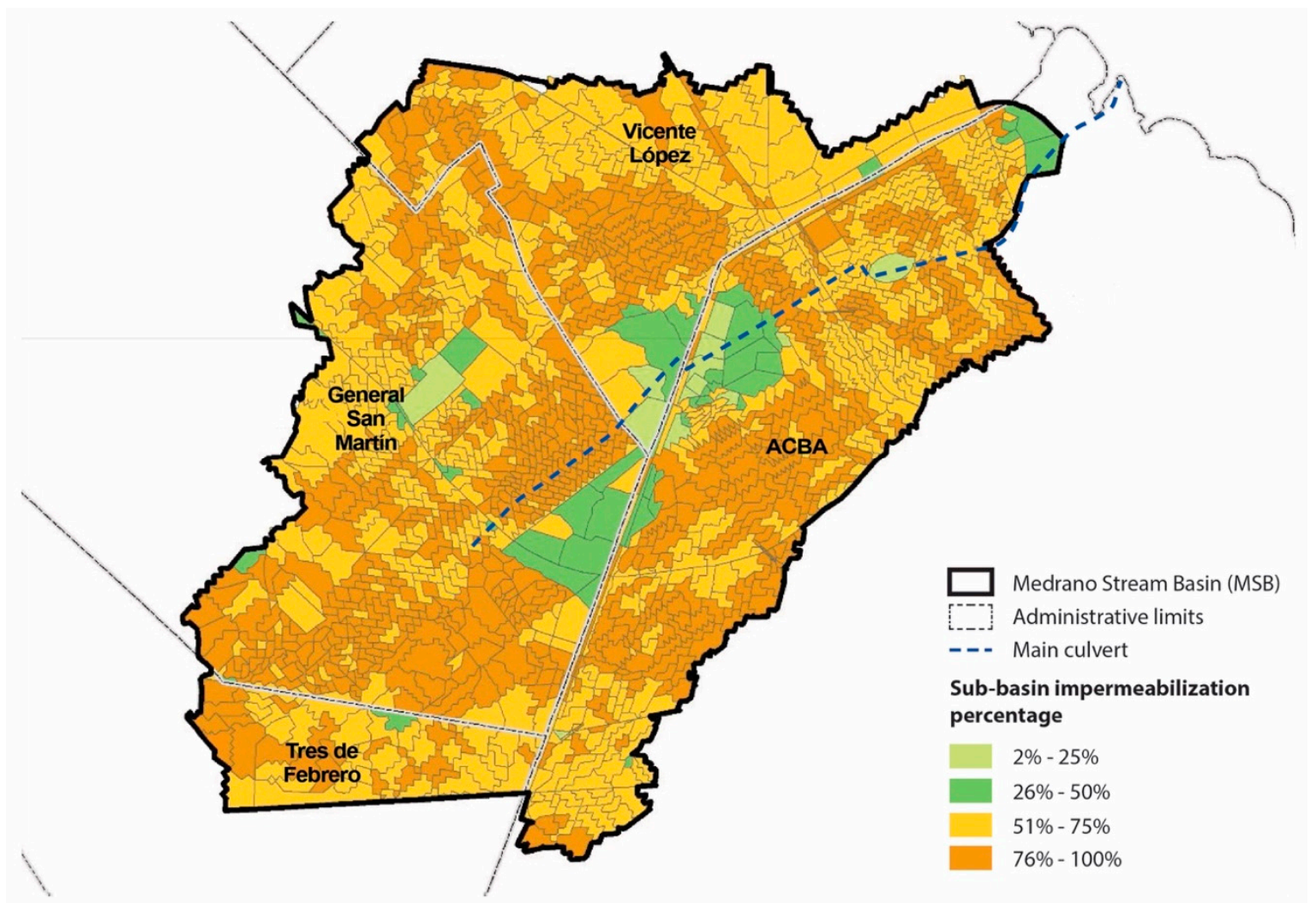

Figure 5. Medrano Stream Basin (MSB) impermeabilization. Source: Translated and adapted from UDMP-MSB [26]. 
In order to examine the extent to which a BGI approach is viable in this setting, this research involved a comparative study across four dimensions: (1) BGI design and urban morphology; (2) land value; (3) hydraulic performance; and (4) politico-institutional questions. The comprehensive approach to this study reflects key areas of international debate in BGI and together represent a first of its kind study for the Latin American region, which to date, has few experiences in applied large-scale BGI and no built deculverting projects.

Based on the preliminary inquiry undertaken, the initial findings suggest that in dense and impervious urban basins it is possible to implement BGI strategies within a hybrid system so as to deliver significant urban sustainability goals. It is through the development of combined BGI/grey infrastructure systems that it is possible to deculvert watercourses that are compatible with Compact City principles.

\section{Materials and Methods}

Given that this research aims to compare a business-as-usual approach to infrastructure planning with a scenario based on BGI, this study adopted a foresight approach as characterized by Godet and Durance $[27,28]$. This was operationalized through a scenario methodology that sought to give an account of different ways of combining possible answers to the same set of questions, with the aim of broadening debate about the advancement of BGI from a Global South perspective and aiding a future public-policy decision-making process locally [29]. In particular, we examined two main scenarios: (1) Major grey infrastructure solutions combined with minor BGI in the form of non-structural scattered SUDS; and (2) structurally important BGI measures with reduced dependency on grey infrastructure. For each scenario, four variables were analysed: (1) Construction Costs; (2) Land-Value Increase; (3) Protection Level against Flood Events; and (4) Untreated Runoff Discharge.

Based on a comprehensive literature review, the first scenario reflects a business-as-usual (BAU) proposal, which at present is the most likely outcome, not only in Argentina, but in Latin America in general. The second scenario was proposed as an exploratory, visioning scenario [30] that aimed to show a significant contrast, while keeping important variables fixed to facilitate the comparison, most significantly the level of protection against floods. An additional possibility was also considered by combining both major BGI and grey infrastructure solutions, but for the purposes of this article, it is only mentioned briefly and when appropriate.

In order to build these scenarios, data collection and analysis were conducted over an intensive period of one year (2019), involving iterative phases of literature review, including international case comparisons, a collaboration with a university urbanism studio to generate baseline design options, site visits, preliminary hydraulic analyses, and semi-structured interviews with ten stakeholders from all three levels of government and multilateral development banks (the main funding bodies of large scale infrastructure in the region). For each method adopted, the focus was on exploring different opportunities and challenges associated with grey infrastructure versus BGI for integrated management of the MSB in the Metropolitan Region of Buenos Aires (MRBA).

The literature review provided background knowledge about the way in which BGI has been adopted in other cities and what typical challenges exist in advancing a BGI agenda in dense urban settings. Current debates illuminated a particular gap in pursuing both a compact city agenda with BGI in terms of managing social flood risk. Other aspects uncovered among current debates related to institutional challenges associated with BGI vis-à-vis grey infrastructure, from financing to maintenance and socio-political resistance to managing engineering uncertainty. Some of these aspects were developed further in this research with a view to contextualising these general trends.

Following the literature review and definition of key points in the debate around the suitability of BGI in dense urban settings, the method involved collaborative work within the framework of a live project undertaken in an urbanism studio at the Faculty of Architecture, Design and Urbanism, University of Buenos Aires (FADU-UBA). In essence, the students worked with the research team to elaborate possible urban design solutions for accommodating BGI within the dense MSB. Their 
brief included preliminary engineering details for water carrying and retention capacities, as well as a design framework based on Low-Impact Development (LID) principles, including, for example, the maximisation of permeable spaces and the inclusion of stormwater retention devices. Possible design solutions were collaboratively developed to test the possibility of transitioning from grey to BGI along the length of the watershed, including, for example, new building guidelines along with foresting, retention ponds, deculverting and floodable parks.

Once these scenarios were finalised, a preliminary examination for engineering viability and performance was undertaken. The differential costs and benefits of grey versus BGI were estimated across the areas of flood reduction, pollution, construction, and financing. Part of this phase of the research also involved a study of property market tendencies to gather evidence about possible land value increases as a result of flood reduction and urban space improvements (e.g., increased green space and new quality public space), which may add to the attractiveness of BGI in terms of financing through public surplus-capture instruments [31] and garnering sufficient political support. This is an especially important facet of assessing the viability of moving from a BAU to a BGI approach in the Latin American region given the limits of local funding for infrastructure generally.

In this regard, it was clear from the literature review that technical viability was not the only element or even the most important variable for adopting BGI: Instead, the greatest challenges lie in the necessary political agreements and institutional transformations required to implement the coordinated and complex adoption of BGI. For this reason, the final stage of this research involved conducting semi-structured interviews with predominantly institutional stakeholders and interpreting these empirical data on the opportunities and challenges of BGI specifically for the local context. These were conducted with public servants from all three levels of government with different areas focused on water and environmental management, public works, parks and urban planning, some members of the basin's management committee (CICAM) and representatives from multilateral development banks involved in financing and managing different aspects of the current proposal for engineering works.

\section{Results}

\subsection{A Study of Four Variables in Two Scenarios}

\subsubsection{Scenario 1: Major Grey Infrastructure, Minor BGI}

Scenario 1 was based on the recent Urban Drainage Master Plan for the Medrano Stream Basin (UDMP-MSB) of CH2M Hill Argentina [26], financed with resources from the European Commission through the Spanish Agency for International Cooperation for Development (AECID) and the Inter-American Development Bank (IDB). It was submitted to the Basin Committee for the Medrano Stream (CICAM) in February 2019 and is pending approval for construction. This scenario allowed us to examine with a high degree of reality the predominant approach in Argentina and Latin America. In this case, a 10-year return period event was previously established by the Master Plan of Hydraulic Planning for the ACBA [32] to define the new works required. This resulted in a system of an in-depth $10 \mathrm{~km}$ main relief tunnel with an internal diameter of $7 \mathrm{~m}$, complemented with a secondary relief tunnel of $3.5 \mathrm{~m}$ of internal diameter.

In this scenario, the addition of SUDS as non-structural measures contributes modestly to the performance of the system, but was not taken into account when the relief tunnels were sized, because at the adopted scale it had a very marginal impact. The planned SUDS would provide amenity and environmental services in the specific and limited places where they would be located. Above all, they were included to fulfil a symbolic function, responding to a growing tendency towards the incorporation of sustainable development approaches sponsored by multilateral funding agencies. 


\subsubsection{Scenario 2: Major BGI, Minor Grey Infrastructure}

In Scenario 2, an inversion of terms was considered: Specifically, a main BGI system complemented by reduced grey infrastructure support. For this, the baseline designs produced at an urbanism studio course at FADU-UBA were utilized as the starting point for the design vision. The main aim of the exercise was to increase, as much as possible: (1) The absorbent surface area in the watershed, (2) the capacity of water retention using multiple BGI strategies, and (3) the conduction of the open stream course through a deculverting design. With this input, the complementary grey infrastructure that would be needed to achieve the same level of protection of Scenario 1-a 10-year return period-was then calculated. Subsequently, three other variables were also estimated: Its cost, the increase in land value and the untreated runoff at the stream mouth as an indication of contamination levels.

In terms of system performance, in the second scenario, the vast majority of potential flood events would be managed by BGI, which would provide an opportunity for improved quality of water at the mouth of the Medrano Stream which discharges into the de la Plata River. In this regard, the grey infrastructure - the underground relief tunnels-would perform the function of an 'emergency valve' that would be activated only in those cases in which the BGI capacity would be exceeded. This means that the underground relief tunnels would not be filled simultaneously with the existing culvert as the storm event develops-as is usually the case in conventional grey infrastructure-but only by overflow, once the absorption and retention of the system would become saturated. In other terms, the relief tunnels would not be used for daily stormwater flow in the basin. In a best-case scenario, they would play a role only in exceptional storms, and as a combined approach, add to overall system resilience. The design of these systems would require complex overflow structures based on difficulties in establishing an optimum level to transfer water from the existing system to the relief tunnel. However, they would significantly reduce contamination at the mouth of the stream.

Figure 6 shows the existent, as well as the proposed absorbent surface identified in the MSB along with the existent and proposed open reservoirs for Scenario 2. Figure 7 shows schematic sections across the Medrano Stream for Scenarios 1 and 2.

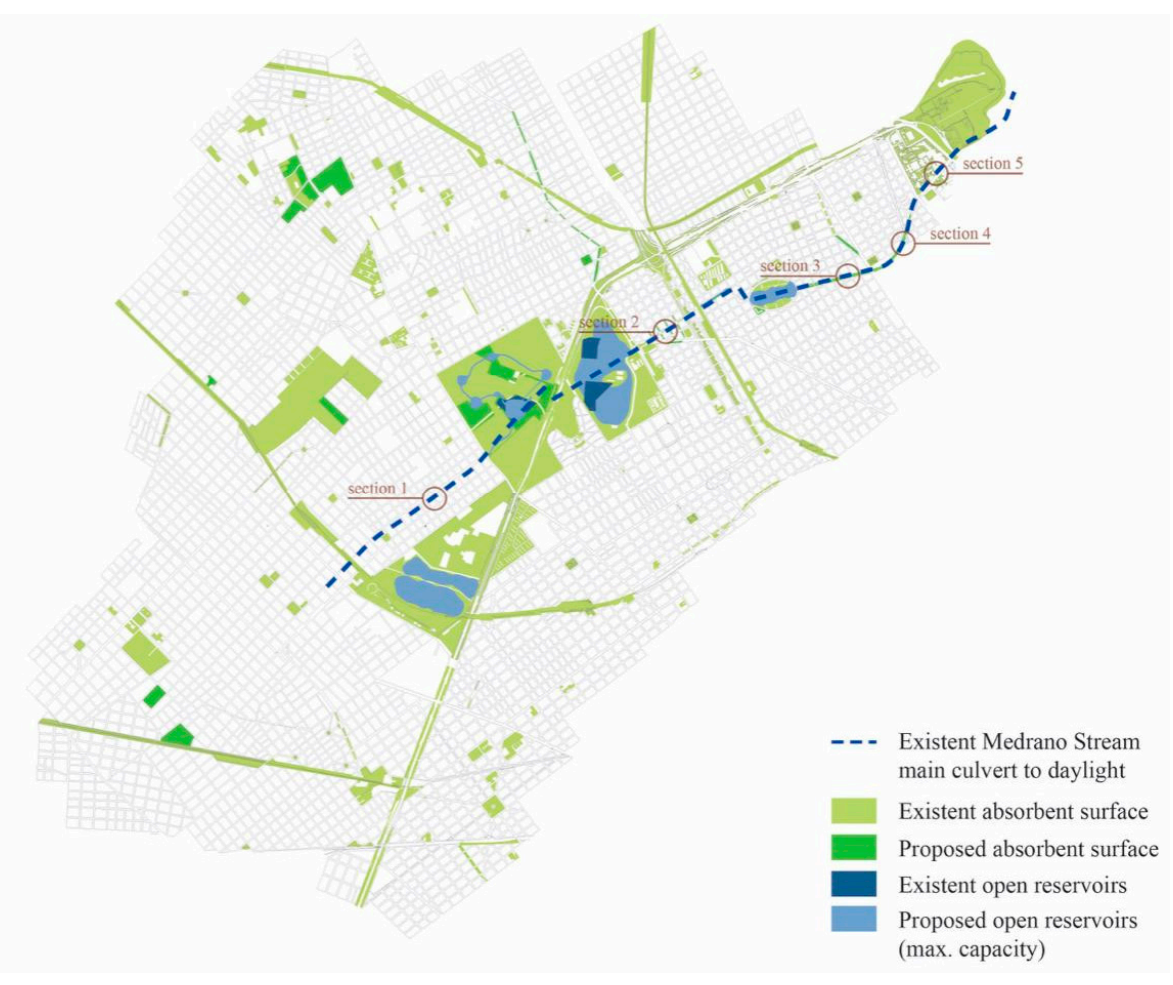

Figure 6. Absorbent surface and reservoirs proposed for Scenario 2. 
Scenario 1: Major grey infrastructure, minor BGI
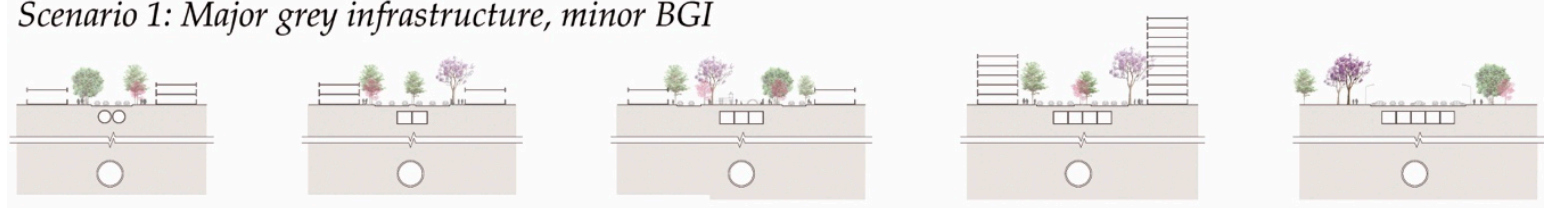

Scenario 2: Major BGI, minor grey infrastructure

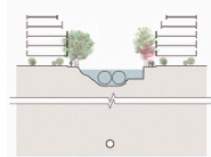

Section 1

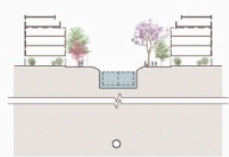

Section 2

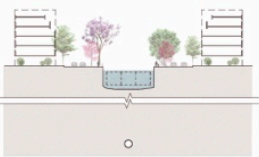

Section 3

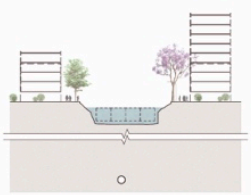

Section 4

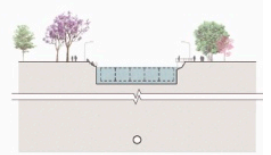

Section 5

Former culverts

Maximum Build Height

according to current normatives

Figure 7. Schematic sections for the Medrano Stream in Scenarios 1 and 2.

\subsection{BGI Design and Urban Morphology}

As previously mentioned, the initial proposals developed in the urbanism studio were used as a starting point for the analysis of Scenario 2 and were modified via the identification, delimitation and qualitative exploration of potential spaces that would accommodate BGI components, which in turn would enable a quantitative analysis beyond the university class setting. In particular, the studio exercise consisted of elaborating urban projects in six sections of the Medrano Stream that aimed to increase the absorbent surfaces, propose stormwater retention strategies in open reservoirs, floodable parks and new afforestation. The projects also contemplated the design of a deculverted watercourse, not only with the aim of expanding the volume of water conveyed, but also as a socio-environmental contribution, through the enhancement of the quality of water and production of new public space (Figures 8-11).
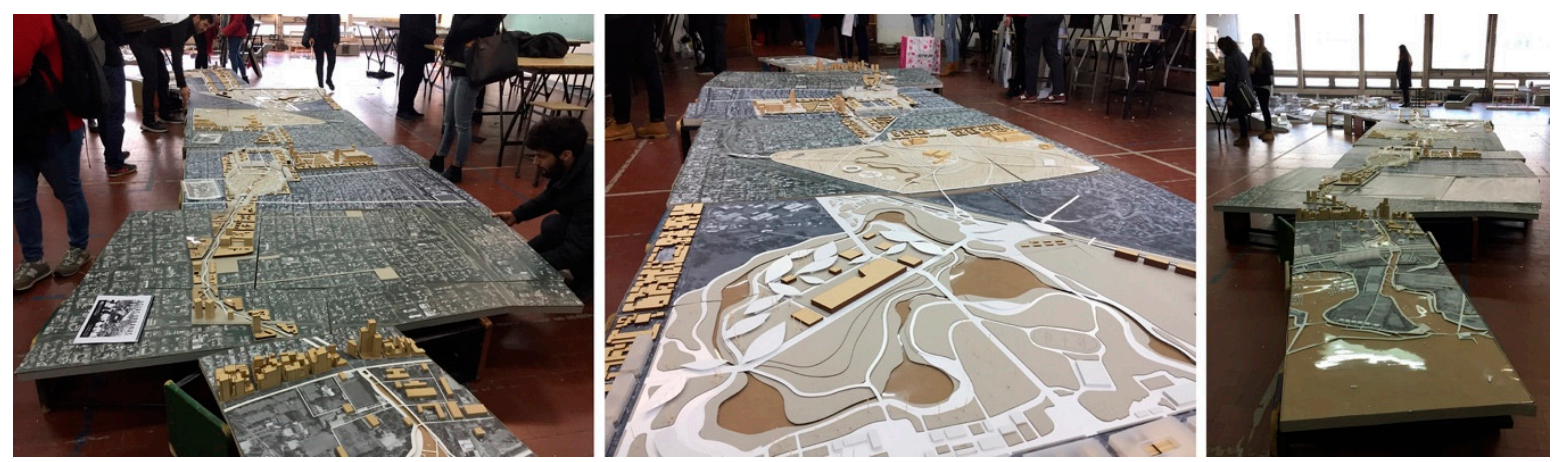

Figure 8. BGI proposals for the Medrano Stream Basin (1:1000 model). Credits: Proyecto Urbano, Taller Grinberg 2019, FADU-UBA. Tutors: Busnelli, Kozak, Feldmann and Cardini. Students: Aleman, Arnaudo, Bartolucci, Santini, Tossi, Martinez Galvez, Tahan, Cortes Guerrieri, Galdeano, Viale, Castroman, Soto Barrientos, Politis, Lennon, Pontoni, Costa, Villalba, Erazo, and Lucas. 

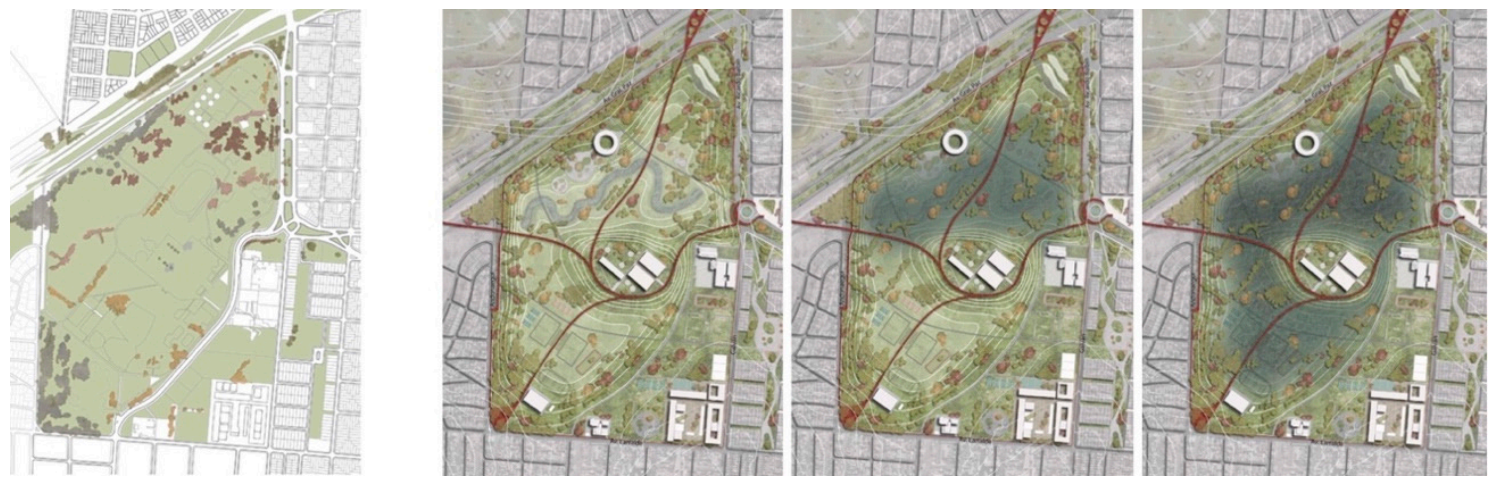

Figure 9. (a) Existent Sarmiento Park; (b) Sarmiento Park redesigned, with its open reservoir shown at three levels of its capacity filled. Credits: Proyecto Urbano, Taller Grinberg 2019, FADU-UBA. Tutors: Busnelli, Kozak, Feldmann and Cardini. Students: Aleman, Arnaudo and Bartolucci.

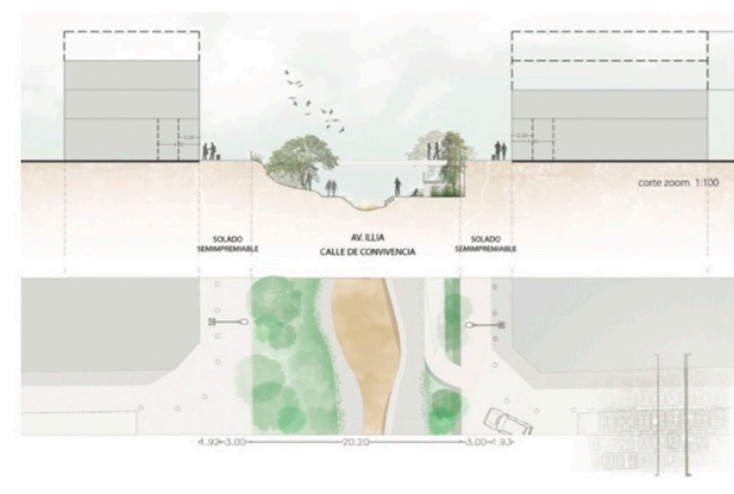

(a)

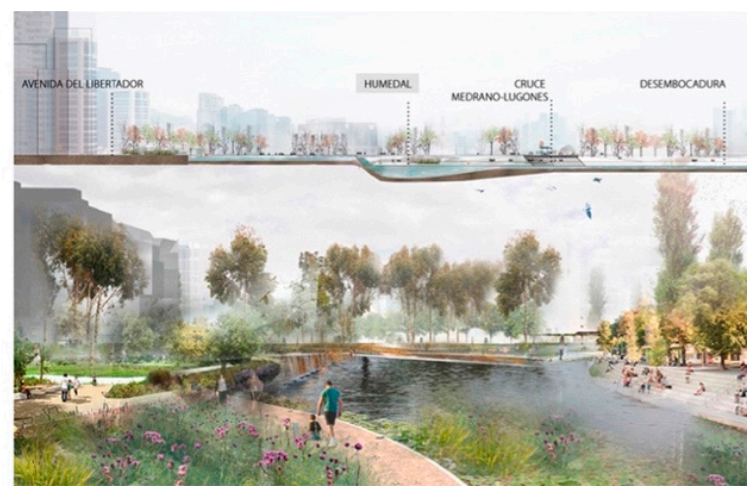

(b)

Figure 10. Deculverting design proposals. (a) The typical section at the upper basin; (b) section at the mouth of the Medrano Stream and proposed wetland. Credits: Proyecto Urbano, Taller Grinberg 2019, FADU-UBA. Tutors: Busnelli, Kozak, Feldmann and Cardini. Students: (a) Tossi, Martínez Gálvez, Tahan and Santinti; (b) Lennon, Costa and Pontoni.
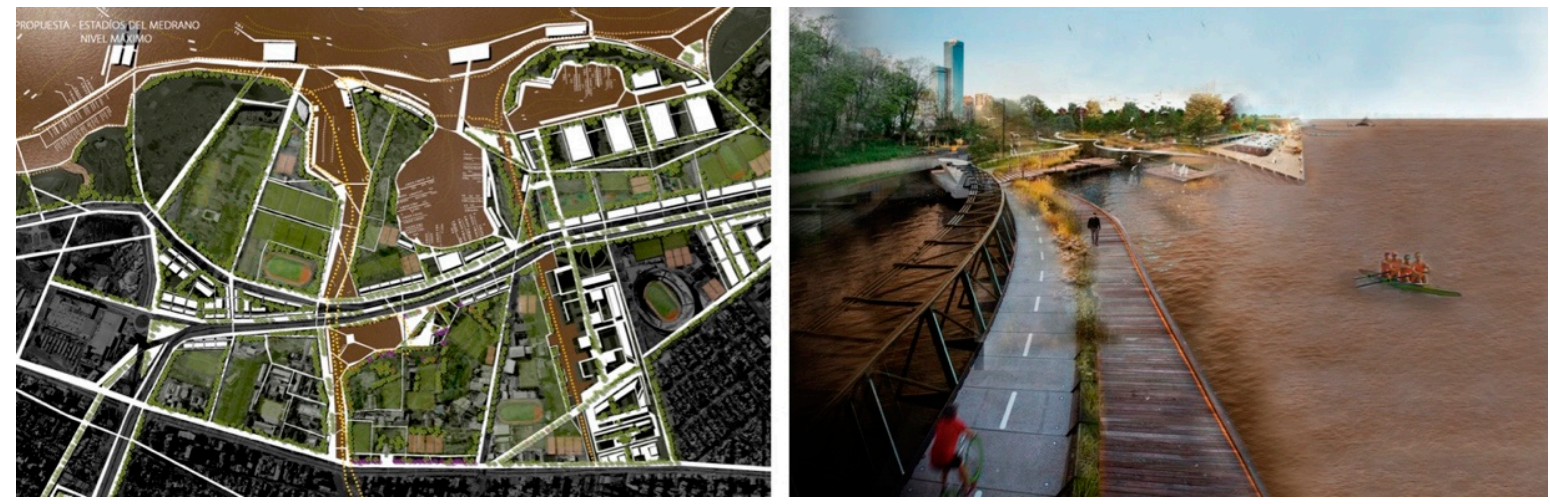

Figure 11. Design proposals at the Medrano Stream mouth, reaching the de la Plata River. Credits: Proyecto Urbano, Taller Grinberg 2019, FADU-UBA. Tutors: Busnelli, Kozak, Feldmann and Cardini. Students: Lennon, Costa and Pontoni.

Fundamental to this exercise was the notion of designing in the terrain of water [33]. This involved conceiving the urban projects not only in terms of space, but most importantly with regards to the planning of time: The idea that the presence of water in cities could be in a sense programmed. This meant making room for the river-as one Dutch initiative put it [34] - as well as anticipating the 
different conditions that those spaces of water would adopt throughout time. The challenge in this sense is in part socio-cultural; it requires overcoming the perception of a flooded park as a negative contingency by transforming it into an opportunity to recreate new valued landscapes and uses, equivalent to a snowed park, for example, see Figure 9.

Such transformations also presented the need to reflect on required urban planning and building-code changes that would better adapt the urban morphology of the MSB to the proximity of water, for example, from architectural typologies to urban densities. The general conclusion of the studio was finding a way to achieve a balance between moderately increasing the building capacity of city blocks, which could also moderately increase the population density, in order to trigger a process of urban transformation that would allow the replacement of one or two-story residential buildings to mixed-use four-story buildings with smaller footprints. These smaller building footprints would leave more absorbent surfaces and minimize the hazard-exposure of residential uses at the sidewalk level in flood-prone areas by promoting non-residential uses on the ground floor, among other benefits.

Based on the proposals prepared in the studio, the research team carried out a review and alignment process to generate Scenario 2, by adapting the projects to the urban development reality of the city and design feasibility, evaluating the levels of flood protection achieved, and estimating the reduction in the levels of runoff (and contamination). Below both scenarios are examined in relation to the four dimensions of analysis adopted.

\subsection{Hydraulic Performance and Hydric Condition of the Medrano Stream: Preliminary Analysis}

The initial urban form analysis and design visioning exercise confirmed the high level of density in the MSB and the lack of public open space left for natural stormwater function. The city of Buenos Aires is an emblematic example of a model of high density urbanization materialised progressively with culverted streams forming a network of storm drains under a clear evacuation concept. In the Medrano Stream, this drainage network is structured around tributary culverts that follow natural flow directions, except towards the mouth of the stream, where it is an open channel with a section width that varies from $30 \mathrm{~m}$ to $70 \mathrm{~m}$. The history of the development of this drainage network shows a clear bias towards the construction of culverted works and the implementation of retention areas for flood mitigation. The most important milestones in the construction of the Medrano Stream drainage system were formed by the construction of the main collector (1930-1940); the construction of two new storm alleviation conduits (2003 onwards); the construction of retention areas in the Sarmiento Park (2014-2015); and the construction of secondary conduits and small floodable plazas in Vicente López (2016-2017).

In terms of water flows, and for the basic hydraulic analysis, the MSB requires the management of a total runoff of $450 \mathrm{~m}^{3} / \mathrm{s}$ for a 10-year recurrent storm event. It receives the contribution of several secondary branches totalling $52 \mathrm{~m}^{3} / \mathrm{s}$ and $47 \mathrm{~m}^{3} / \mathrm{s}$ on the right and left stream banks, respectively. The current hydrological runoff demand produced by the basin is not, however, matched by the hydrological conveyance capacity of system's trunk culverts, which currently deliver a total flow of $140 \mathrm{~m}^{3} / \mathrm{s}$ for a 10-year return period event. The deficit existing between the production of runoff (demand) and what the system can effectively handle from a hydraulic point of view (supply) is very high, reflecting a level of infrastructure that is generally undersized even for periodic 2-year return period events, causing undesired flooding situations.

The development of grey infrastructure works is not enough to respond to the health and social wellbeing of the residents of the MSB, the current climate context, and the high vulnerability that the city has reached after many years of urban development with a high degree of detachment from local water history. Surface water surpluses in areas with impermeabilized levels of over $90 \%$ cannot be managed without resorting to major infrastructure works. However, it is becoming difficult or technically impractical to design grey infrastructure works exceeding a standard of protection of 10 to 20 years. Furthermore, engineering works generate an excessive sense of security. For example, culverting and removing from sight watercourses lead to a decrease in the perception of risk in 
society. People become accustomed to the absence of water, and this tends to increase demand to further the level of impermeabilization. Essentially, society previously had a better awareness of flood hazards when living with the natural periodicity of out of bank flows. These considerations increase the demand for innovative and sustainable solutions to stormwater management, as represented in Scenario 2 below.

For this preliminary analysis and comparison, simplified hydrological calculations, based on a topographical and spatial analysis, were made to examine the performance of the two scenarios.

\subsubsection{Scenario 1: Major Grey Infrastructure, Minor BGI}

This scenario reflects the Master Plan for Urban Drainage in the Medrano River Basin (UDMP-MSB) submitted in 2019 [26], which describes a series of grey infrastructure structural measures to provide a standard of protection against a storm event of a 10-year return period with three key components:

1. A main relief tunnel that increases the total discharge capacity of the basin of $10 \mathrm{~km}$ in length and $7 \mathrm{~m}$ in internal diameter, parallel to the existing trunk duct and at depth, that increases the total discharge capacity of the system;

2. A secondary relief tunnel of $3.5 \mathrm{~m}$ in internal diameter, which extends into the upper part of the basin in San Martin and Tres de Febrero;

3. The construction of more than $55 \mathrm{~km}$ of new conduits, both as reinforcements of existing ducts and new pipes along streets not currently served. This is further complemented by the construction of 139 new street gullies in the basin.

The total peak flow capacity of the system proposed by the UDMP-MSB is $290 \mathrm{~m}^{3} / \mathrm{s}$ for a return period of 10 years. Through these conveyance works, $65 \%$ of the total runoff generated in the basin would be managed. An estimate of the investment costs calculated for the main works is presented in Table 1.

Table 1. Summary of construction costs for Scenario 1 (UDMP-MSB).

\begin{tabular}{|c|c|}
\hline Construction & Construction Costs (USD) * \\
\hline 1. Main relief tunnel & 240 million ** \\
\hline 2. Secondary bypass tunnel & 90 million ** \\
\hline 3. Reinforcement works & 111 million ** \\
\hline Total & 441 million ** \\
\hline
\end{tabular}

\subsubsection{Scenario 2: Major BGI, Minor Grey Infrastructure}

This scenario prioritizes the use of BGI as the main response to drainage requirements, leaving the natural system to recover part of its historical functioning. BGI interventions in the Medrano Stream are classified into two types: As deculverted sections of the stream and as reservoirs that would favour the attenuation of peak flows, thus, reducing the size of complementary grey infrastructure downstream. The present preliminary analysis only accounts for the attenuating effects of peak flows of four reservoirs projected in open areas, which are the most significant changes that would be introduced in terms of the performance of the system. BGI interventions in the deculverting of the stream have not been computed in the calculation of the hydrological capacity of the basin and remain for future works.

The volume of the four proposed reservoirs significantly increases the storage capacity of the Medrano Stream (Figure 12). The first proposed reservoir which experiences frequent flooding problems in the Mitre area, offers significant potential for attenuation as it is in an area where many sources of runoff from the upper basin converge. A phreatic level located at $13 \mathrm{~m}$ was assumed. The natural terrain level in this area is on average $15 \mathrm{~m}$, generating a usable volume of this reservoir of 
$208,881 \mathrm{~m}^{3}$. The second proposed reservoir, in the urban area of Tecnópolis, currently has an attenuation volume of about $340,000 \mathrm{~m}^{3}$. The intentions of the BGI proposal here are to deculvert the stream at the entrance of the reservoir and introduce a series of interconnected reservoirs in the surrounding area, significantly increasing the capacity of the existent reservoir (see Figure 4). The initial level of the reservoir is maintained at $8.00 \mathrm{~m}$, and the surrounding land is between $12 \mathrm{~m}$ and $14 \mathrm{~m}$, so a usable volume of $581,887 \mathrm{~m}^{3}$ was estimated. The third proposed reservoir, in Sarmiento Park, essentially consists of deculverting the stream and providing a large reservoir that can operate in a line. Assuming a phreatic level of $7 \mathrm{~m}$ and a natural terrain level of $10 \mathrm{~m}$ as the reservoir top, a usable volume exists of $819,140 \mathrm{~m}^{3}$. The terrain level of the facilities in the park beyond the floodable area is close to $12 \mathrm{~m}$. Finally, the fourth reservoir corresponds to a low area in Saavedra Park. The initial levels in this reservoir would range from 3 to $4 \mathrm{~m} \mathrm{NGI}$, with a maximum terrain level of $7 \mathrm{~m}$ NGI that would provide a usable potential reservoir of $147,527 \mathrm{~m}^{3}$.

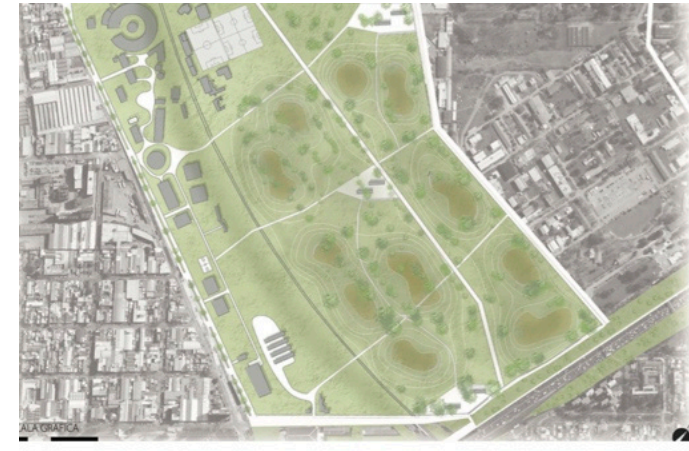

Mitre reservoir

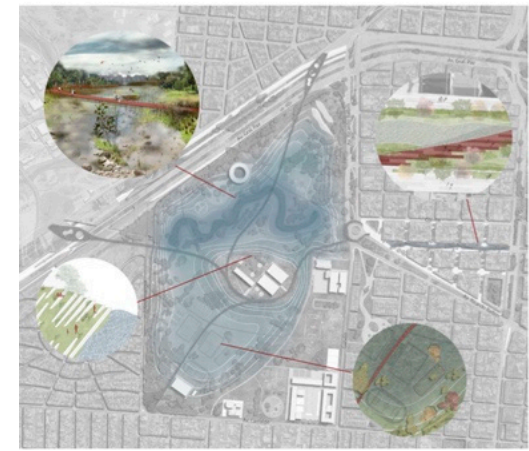

Sarmiento reservoir

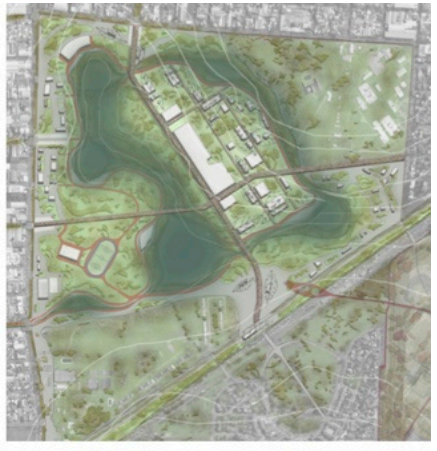

Tecnópolis reservoir

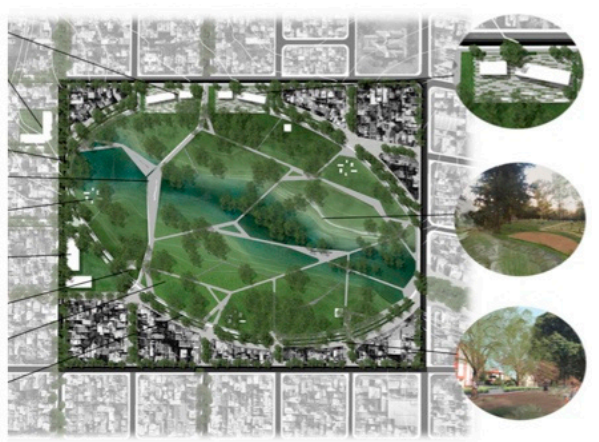

Saavedra reservoir

Figure 12. Four proposed reservoirs at the MSB. Credits: Proyecto Urbano, Taller Grinberg 2019, FADU-UBA. Tutors: Busnelli, Kozak, Feldmann and Cardini. Students: Aleman, Arnaudo, Bartolucci, Santini, Tossi, Martinez Galvez, Tahan, Galdeano, Viale, Castroman, Soto Barrientos, and Politis.

\subsubsection{Comparative Analysis and Cost Reduction Compared to Scenario 1}

In terms of hydraulic capacity, the BGI scenario presents a reduction in surface runoff through an increase in the absorbent areas in the basin that goes from 24\% (UDMP-MSB) to $26 \%$ with the incorporation of BGI. In addition, there is an increase in the storage capacity of the basin, which totals approximately 1.42 million $\mathrm{m}^{3}$. The proposed reservoirs, in this sense, have an attenuating effect on the proposed peak incoming flows by $40 \%$, based on the operation of existing works, leaving a residual volume of 0.52 million $\mathrm{m}^{3}$ that would still need to be managed by grey infrastructure. The latter represents the target volume for sizing complementary engineering works for a further relief tunnel, estimated at a flow of $70 \mathrm{~m}^{3} / \mathrm{s}$.

Given that the tunnel construction cost of Scenario 1 is approximately USD 330 million (see Table 1), and that it delivers a flow of $150 \mathrm{~m}^{3} / \mathrm{s}$, this would give a unit cost of approximately USD 
2,200,000 for each $\mathrm{m}^{3} / \mathrm{s}$ delivered. Applying this same relationship, the cost of Scenario 2 to deliver a flow exceeding $70 \mathrm{~m}^{3} / \mathrm{s}$ is estimated at USD 154 million. Table 2 summarizes these costs.

Table 2. Summary of grey-infrastructure construction costs for Scenario 2.

\begin{tabular}{lcc}
\hline \multicolumn{1}{c}{ Construction } & Unit Cost (USD $\times \mathrm{m}^{3} / \mathrm{s}$ Delivered) & Construction Cost (USD) \\
\hline $\begin{array}{l}\text { 1. Main relief tunnel } \\
\text { 2. Secondary bypass tunnel }\end{array}$ & 2.2 million & 154 million * \\
\hline 3. Reinforcement works & & 111 million * \\
\hline Total & & $\mathbf{2 6 5}$ million * \\
\hline
\end{tabular}

${ }^{*}$ Rounded values.

In addition to grey-infrastructure, Scenario 2 also involves BGI costs, which for the means of this analysis were simplified in two categories: New green space area and deculverting area. Based on data provided by the Municipality of San Martín and the Autonomous Government of Buenos Aires, the former was calculated with a unit cost of USD 100 per square metre and the latter with a unit cost of USD 450 per square metre, which gives a total of USD 128 million (Table 3).

Table 3. Summary of BGI construction costs for Scenario 2.

\begin{tabular}{lccc}
\hline \multicolumn{1}{c}{ Construction } & Area $\left(\mathbf{m}^{\mathbf{2}}\right)$ & Unit Cost $\left(\mathrm{USD} / \mathbf{m}^{\mathbf{2}}\right)$ & Construction Cost (USD) \\
\hline 1. New green space & 884,771 & 100 & $88,477,100$ \\
2. Deculverting area & 88,140 & 450 & $39,663,000$ \\
Total & & & $\mathbf{1 2 8}$ million $^{*}$ \\
\hline
\end{tabular}

${ }^{*}$ Rounded values.

The third component of the hydraulic analysis considered contamination. Specifically, the volume of untreated runoff that would be discharged into the de la Plata River was estimated using the total surface runoff moved by the conveyance system as a surrogate to establish the notional pollutant load discharged.

Scenario 1 involves a major expansion of the current conveyance system by accommodating a significant portion of the excess runoff that otherwise accumulates on the surface, causing flooding and damage. For this reason, however, it would exacerbate the current level of contaminant load discharged into the de la Plata River for the entire spectrum of storm events. Furthermore, given that the first inch of rainfall is normally associated with the largest contribution of surface contaminants (the so-called first flush runoff) the development of a secondary drainage network will have an adverse impact during the less frequent, but more intense events.

Scenario 2, with the inclusion of more storage areas, as well as other distributed BGI measures, will cause a significant reduction in the initial runoff of around $40 \%$ less in the drainage system, which will have a direct impact on the nominal contaminant load discharged to the de la Plata River. In addition to this, the complimentary grey infrastructure required, if designed to purely work on a alleviation basis by overflow from the deculverted watercourse to the new alleviation tunnel, would be targeted to manage the peak surface runoff; i.e., it would convey the peak flows in excess of the capacity of the existing one. This concept deviates from traditional flood alleviation schemes which increase the conveyance capacity of the existing systems not by overflow, and therefore, not only help to convey the peak flows, but also the entire runoff right from the beginning of the storm event. Hence, conventional schemes also increase the displacement of the first-flush component of runoff, which is more detrimental from an environmental perspective.

Furthermore, a significant part of the pollutants contained in the runoff that would be absorbed and moved through the proposed BGI could be neutralized by the phytoremediation capacity of 
certain vegetation selected for their hyperaccumulation function to perform specific remediation tasks [35]. The main contaminants in urban runoff are usually the remains of oil and waste from internal combustion engines, particles of tyres released by use, particularly from the brakes of vehicles, and dirt from the street in general. Two of the most common components in this type of runoff are nitrogen and phosphorus, which are also common nutrients for many plant species and can, therefore, be easily metabolized. Both of these are in fact macronutrients used for agronomic plant growth and can be found in most fertilizers [36]. Other stormwater pollutants, particularly heavy metals, can also be effectively treated by bioretention systems, with a removal efficiency of above $85 \%$ [37]. In general, phytoremediation strategies are at the forefront of landscape remediation, not only in terms of water, but also with regards to soil and air. They are the most environmentally friendly and cost-effective approach of sequestration, capturing and/or metabolizing contamination [35-39]. Thus, forcing the MSB first-flush runoff to pass through BGI would significantly reduce the overall contamination of the stream basin, and most importantly, would reduce approximately $40 \%$ the first-flush runoff discharged at the de la Plata River, the main drinking source for the approximately 15 million people who live in the Metropolitan Region of Buenos Aires (MRBA).

\subsection{Impact on Land Values}

\subsubsection{Land Value Generation on the Medrano Stream Basin}

Once the viability of the scenarios was established, the analysis focused on two core aspects of implementation: Financing capacity and the local politico-institutional arrangements. In terms of financing BGI, this research explored the possibility of land value capture based on likely valorization processes. The argument is based on the premise that increased flood control and the enhancement of environmental qualities (liveability) in open urban areas have the potential to increase the real estate value of surrounding land and the consequent possibility for the public sector to capture some of that value created for infrastructure investment. First, increased protection against flooding has long been associated with an increased overall value of previously affected properties and savings in avoided damages $[26,40,41]$. Second, it has been broadly argued that the improved environmental qualities of urban spaces increase the real estate value and attractiveness to further develop built-up areas [42-44]. In the context of this study, both Scenarios 1 and 2 increase the level of protection against flood events in the MSB, while only a BGI approach (i.e., Scenario 2) improves environmental qualities and urban liveability. Given that only scenario 2 provides both higher protection and spatial amenities, it is expected to clearly show an increase in per square meter real estate value.

To study land values in the MRBA the best source of data is the built property market because there is an extensive offer of apartments and houses compared to vacant sites. For this reason, built property value is usually used as a proxy to land value (Figure 13). The most noticeable change in the price gradient in the MSB is the administrative boundary between the ACBA and the municipalities of Tres de Febrero, San Martin and-to a lesser degree-Vicente López. This accounts for the positive valuation that the real estate market gives to locations within the ACBA, plus other positive externalities, such as the higher quality of the urban space and coverage of soft infrastructure (mainly education and health services). Another explanatory factor in the ACBA and the north of the MRBA is the proximity to the de la Plata River, with decreasing prices when moving away from its waterfront. Within the MSB the real estate dynamics are also influenced by the flood-prone areas: Prices fall, especially in the ACBA, and the price range is wider (Figure 13). 

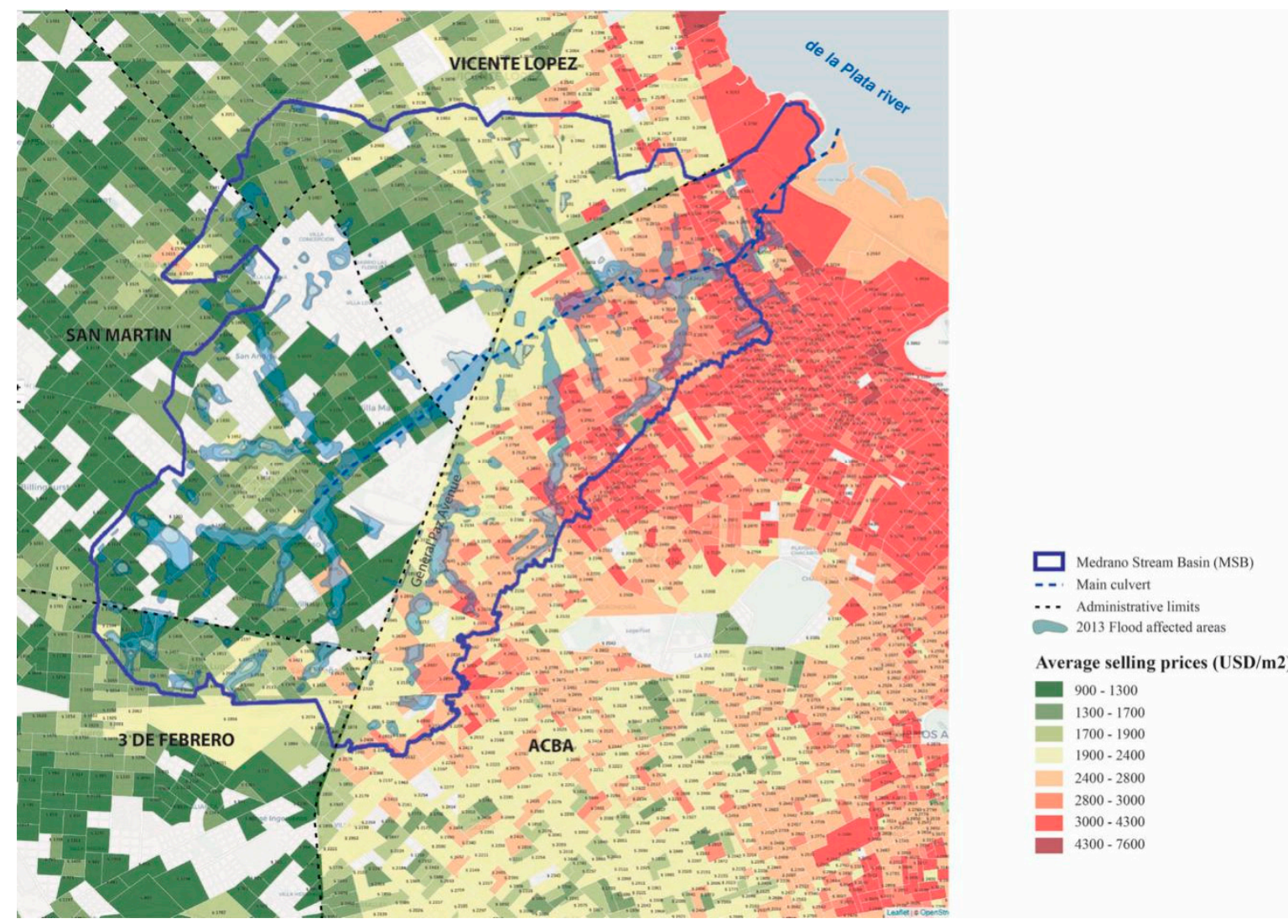

Figure 13. Built property prices and floodable area, MSB. Source: Own elaboration based on data provided by Reporte Inmobiliario [45] and UDMP-MSB [26].

\subsubsection{Land Value Increase of Both Scenarios}

To calculate the expected land value increase in the two scenarios outlined for the MSB, the two aspects described at the beginning of the section were employed: Flood protection-valid for both scenarios-and creation of new public space and amenities in Scenario 2. The value uplift for greater protection against flooding calculated in the UDMP-MSB [26] concluded that the joint valuation of the 23,000 affected plots would be USD 192,453,576 (the plots considered are highlighted in Figure 14). To carry out this calculation, a hedonic price model was built to assess the devaluation that properties in the MSB suffer as a result of flooding, and the extent to which this devaluation would be ameliorated by the measures proposed in the UDMP-MSB [26]. The price of the land/built property includes the value of the land, as well as the buildings constructed if they exist. Following the Urban Land Rent Theory, any valuation of the property by external actions (e.g., flood control) is transferred to the price of the land [46].

The extra land value increase in Scenario 2 is due to the implementation of BGI measures that improve urban environmental quality, deliver new natural landscapes, provide amenities, such as public space and improve environmental outcomes. The BGI measures can be divided into two main types of works: Deculverting and public space creation or improvement that include BGI. Due to the lack of local references to calculate the percentages of land value increase expected with the implementation of Scenario 2, we worked parametrically with the effects observed in similar cases of NBS interventions in other parts of the world that were surveyed in the literature review. In Seoul's Cheonggyecheon case the maximum uplift in the first line of the property next to the new promenade with the deculverted stream reached $33 \%$, as opposed to a $20 \%$ differential that existed prior to the construction of this greenway when an elevated freeway existed in its place [17] (p. 2786). In the regional context, the case of the Paraná River in Rosario (Santa Fe, Argentina) also provides useful 
insights. After the removal of obsolete port and railway infrastructure that prevented public access to the Paraná River waterfront, and the creation of a linear coastal parks, land value proportionally increased in relation to the closeness to the river, reaching an average of $21 \%$ uplift within a 10-block band from the coast [47] (p. 51). In general, a positive impact of $20 \%$ on property values in front of new green, or blue-green, urban space is considered a reasonable starting point for estimating value uplift [42].

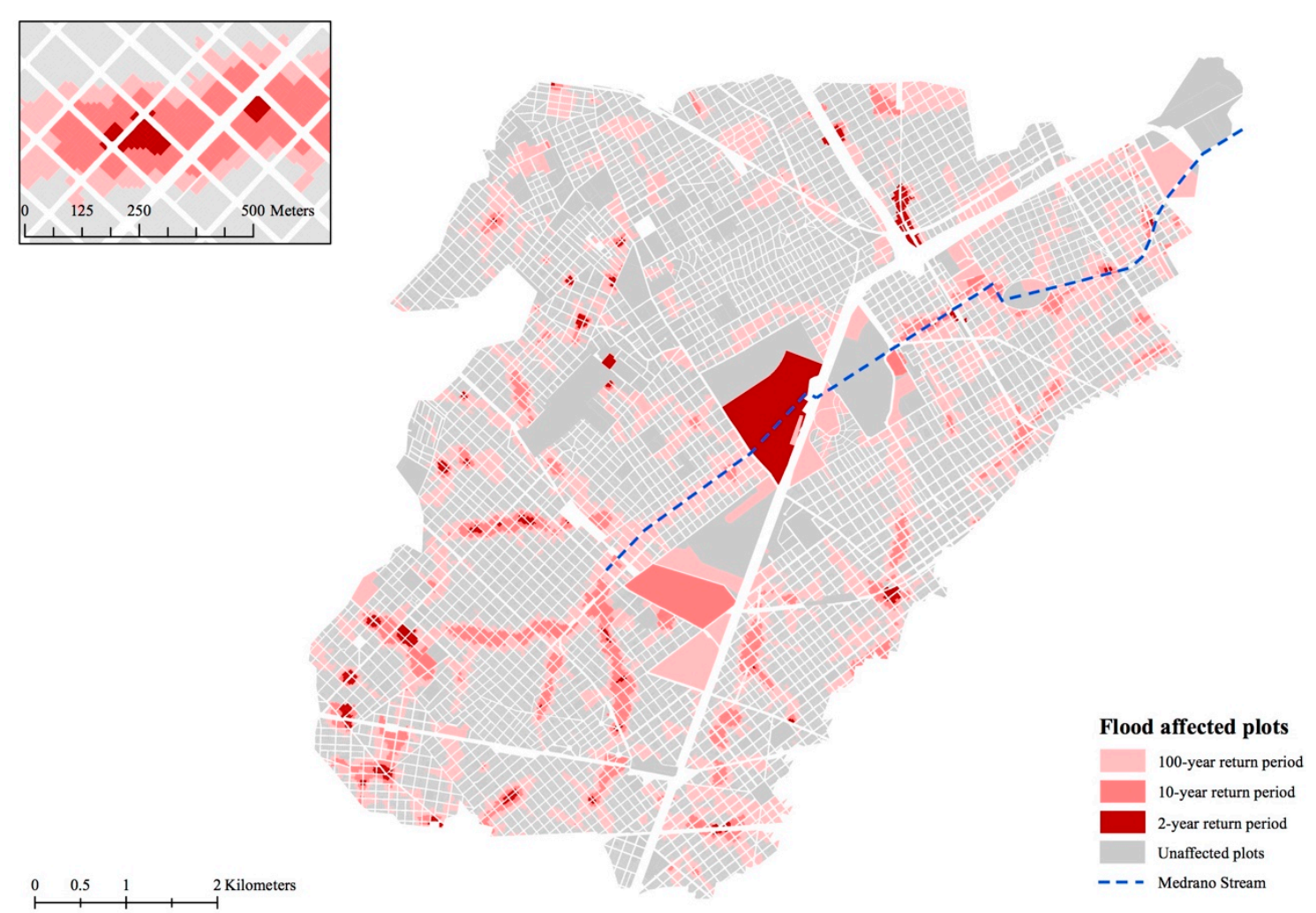

Figure 14. Flood-affected plots that benefit from the proposed increased protection.

To undertake a preliminary study of the effects on land value in the MSB and to calculate the total possible valorization, parameters were established both for the deculverting of the main channel of the Medrano works and for public space creation or reconditioning. For this, two sets of influence buffers were created to determine the affected sites, typifying different situations to apply valorization coefficients. Given the lack of equivalent cases and the uncertainty about the transferability of land value uplift patterns, we opted for a coefficient range instead of a single valorization coefficient. The initial coefficient range adopted for first-line plots facing the new linear park with the deculverted stream was $15-30 \%$.

The deculverting of the main channel requires works of $4923 \mathrm{~m}$ in length. On its margins, there are 686 plots, which extends to some 7891 plots up to $300 \mathrm{~m}$ away that are also considered, distributed in four buffers (Table 4 and Figure 15).

The public space creation or reconditioning involves $7521 \mathrm{~m}$ of perimeter against parcelled areas, which directly benefits 826 plots and positively influences a total of 5643 plots located less than $200 \mathrm{~m}$ away, distributed in 3 buffers (Table 5 and Figure 16). 
Table 4. Plots affected by deculverting works.

\begin{tabular}{|c|c|c|c|}
\hline Deculverting Works & Area $\left(\mathrm{m}^{2}\right)$ & Length (m) & Quantity \\
\hline Deculverting area & 88,140 & & \\
\hline Deculverting length & & 4923 & \\
\hline First line plots & & & 686 \\
\hline Plots up to $100 \mathrm{~m}$ & & & 1360 \\
\hline Plots between $100 \mathrm{~m}$ and $200 \mathrm{~m}$ & & & 2997 \\
\hline Plots between $200 \mathrm{~m}$ and $300 \mathrm{~m}$ & & & 2848 \\
\hline Total plots & & & 7891 \\
\hline
\end{tabular}
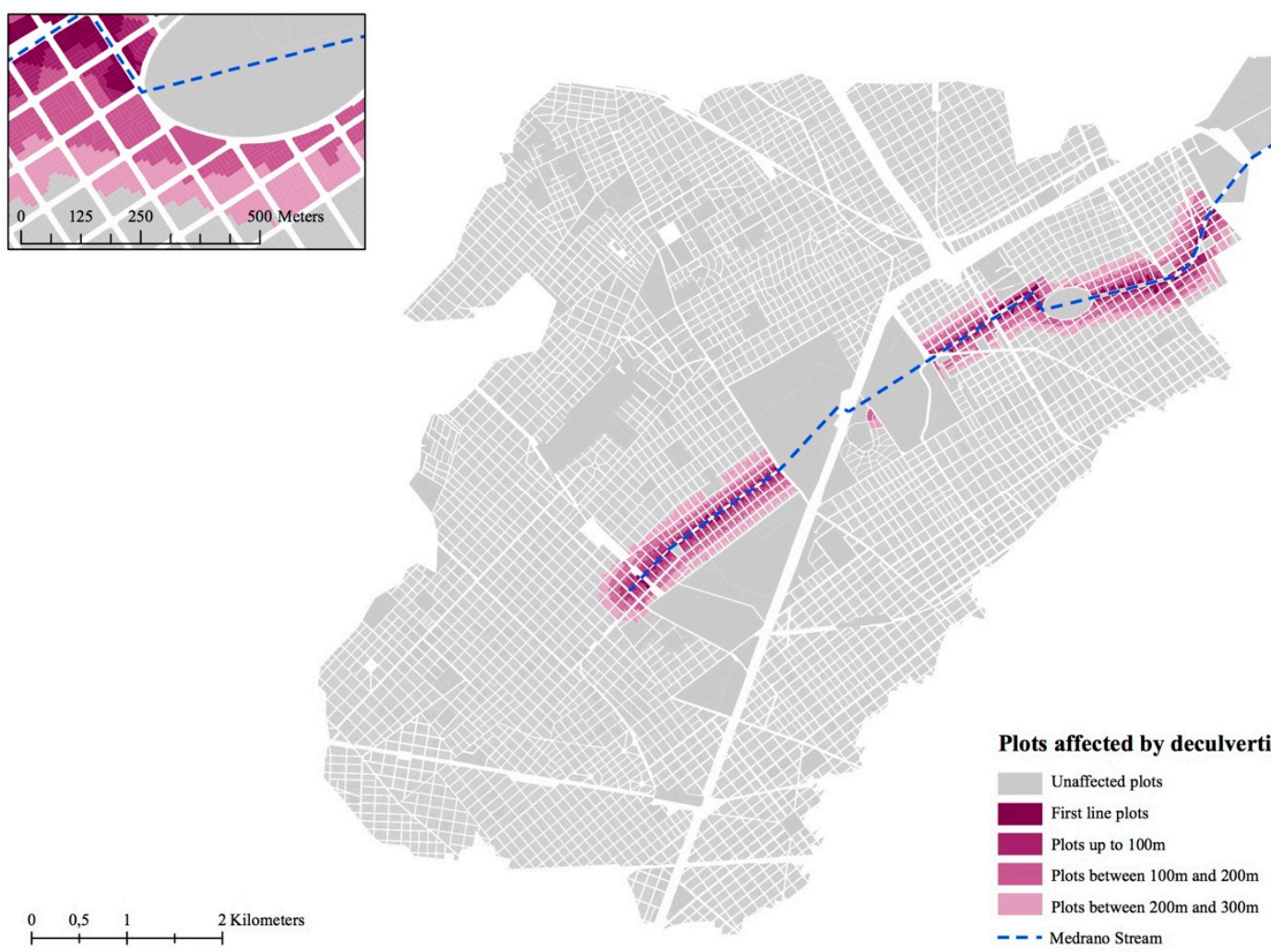

Figure 15. Plots affected by deculverting works.

Table 5. Plots affected by public space works.

\begin{tabular}{|c|c|c|c|}
\hline Public Space Works & Area $\left(\mathrm{m}^{2}\right)$ & Length (m) & Quantity \\
\hline New public space area & 884,771 & & \\
\hline $\begin{array}{l}\text { New public space } \\
\text { perimeter }\end{array}$ & & 7521 & \\
\hline First line plots & & & 826 \\
\hline Plots up to $100 \mathrm{~m}$ & & & 1639 \\
\hline $\begin{array}{l}\text { Plots between } 100 \mathrm{~m} \\
\text { and } 200 \mathrm{~m}\end{array}$ & & & 3178 \\
\hline Total plots & & & 5643 \\
\hline
\end{tabular}




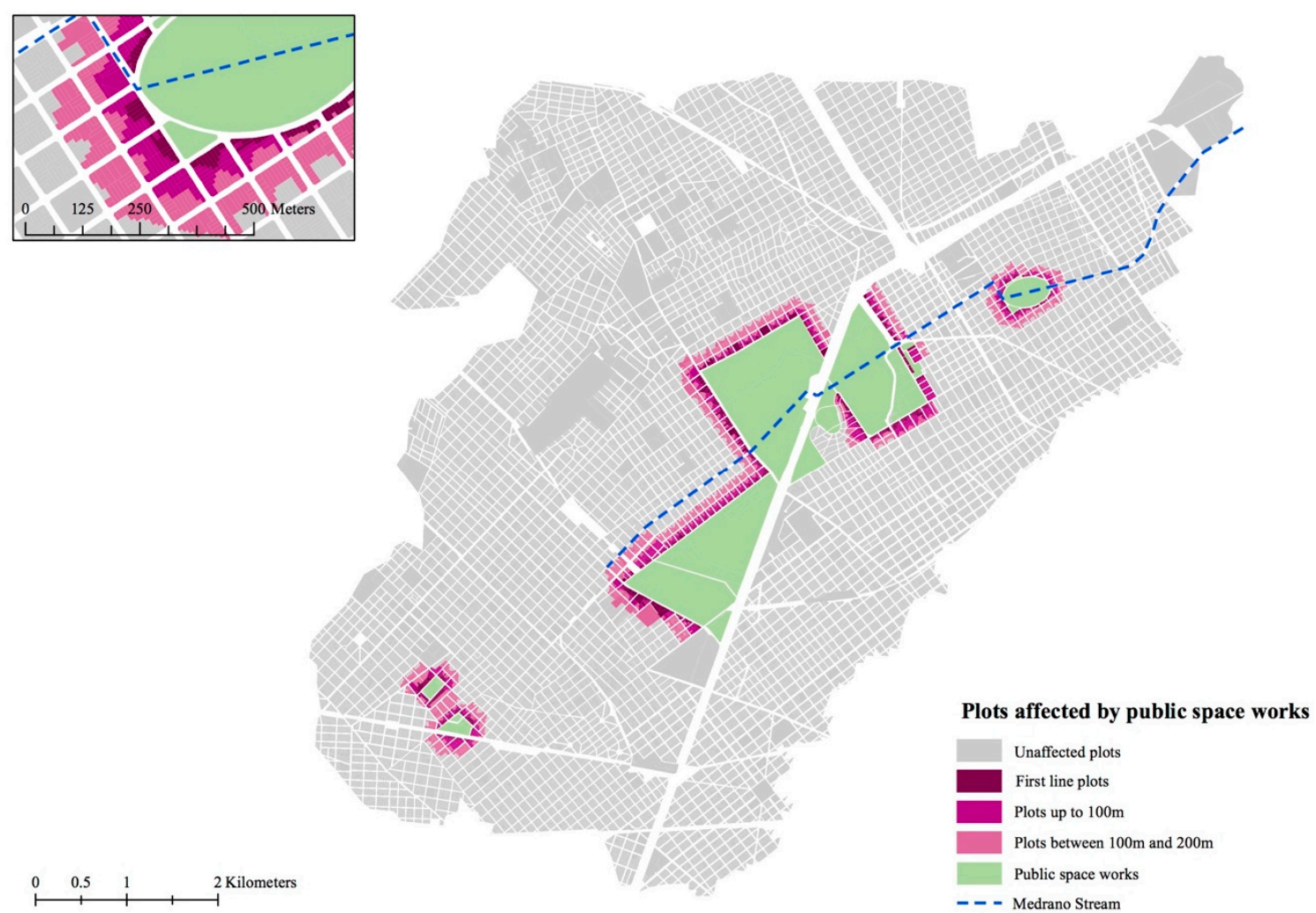

Figure 16. Plots affected by public space creation or reconditioning.

As an initial approach to calculate the land value increase, due to the deculverting of nearly $5000 \mathrm{~m}$ of the Medrano stream with nearly 8000 affected plots and a combined area of 2,112,100 $\mathrm{m}^{2}$, categories based on the distance from the new deculverted stream were established: First line; up to $100 \mathrm{~m}$; between $100 \mathrm{~m}$ and $200 \mathrm{~m}$; and between $200 \mathrm{~m}$ and $300 \mathrm{~m}$. The plots were identified in a GIS platform to facilitate the process (Figure 15). The calculation of the construction capacity of each category was established by adding the correspondent plot area and multiplying by the corresponding maximum FAR allowed by current planning law (summarized in per-category-average values that range between 2.24 and 2.44). This resulted in a combined maximum GFA allowed of 5,077,879 $\mathrm{m}^{2}$ (Table 6).

Table 6. Valorization on plots affected by deculverting works.

\begin{tabular}{|c|c|c|c|c|c|c|c|}
\hline $\begin{array}{l}\text { Deculverting } \\
\text { Works }\end{array}$ & Quantity & Area $\left(\mathrm{m}^{2}\right)$ & $\begin{array}{c}\text { Average } \\
\text { Max FAR }\end{array}$ & $\begin{array}{l}\text { GFA Max } \\
\qquad\left(\mathrm{m}^{2}\right)\end{array}$ & $\begin{array}{c}\text { Average } \\
\text { Land } \\
\text { Value } \\
\text { (USD } / \mathrm{m}^{2} \text { ) }\end{array}$ & $\begin{array}{l}\text { Valorization } \\
\text { Range (\%) }\end{array}$ & $\begin{array}{l}\text { Valorization Range } \\
\text { (USD) }\end{array}$ \\
\hline $\begin{array}{l}\text { First line } \\
\text { plots }\end{array}$ & 686 & 205,745 & 2.44 & 548,100 & 640 & $15-30 \%$ & $74,747,136-149,494,271$ \\
\hline $\begin{array}{l}\text { Plots up to } \\
100 \mathrm{~m}\end{array}$ & 1360 & 370,221 & 2.34 & 939,895 & 650 & $10-20 \%$ & $84,792,674-169,585,349$ \\
\hline $\begin{array}{c}\text { Plots } \\
\text { between } \\
100 \mathrm{~m} \text { and } \\
200 \mathrm{~m}\end{array}$ & 2997 & 773,443 & 2.35 & $1,895,882$ & 704 & $5-10 \%$ & $86,642,424-173,284,847$ \\
\hline $\begin{array}{c}\text { Plots } \\
\text { between } \\
200 \mathrm{~m} \text { and } \\
300 \mathrm{~m}\end{array}$ & 2848 & 762,691 & 2.24 & $1,693,892$ & 666 & $2.5-5 \%$ & $36,231,783-72,463,566$ \\
\hline Total & 7891 & $2,112,100$ & & $5,077,879$ & & & $282,414,017-564,828,034$ \\
\hline
\end{tabular}


To calculate the land value of the affected plots, we used the prices of current built property (apartment and houses) for sale. The alternative of considering only vacant plots for sale was dismissed given their scarcity: Such an approach would have worked against the desired spatial precision, which in this study is paramount as the plots affected by the proposed deculverting have precise locations. Next, the surveyed prices were georeferenced, and the implicit land prices were calculated using the residual method $[47,48]$. The result is a value of per buildable square meter land value associated with each plot of the study area. These values can be summarized, obtaining per-category-average values that range between 640 and $704 \mathrm{USD} / \mathrm{m}^{2}$.

Finally, for each plot its corresponding maximum GFA was multiplied by its per buildable square meter land value and by a valorization coefficient range according to the established buffer distances from the deculverted stream. The land value uplift is considered to be directly proportional to the proximity of the Medrano stream.

As discussed above, rather than a single valorization figure we opted for working with valorization ranges, which better reflect the uncertainty of this type of ex ante land value uplift estimation. A maximum coefficient range was adopted for the buffer closest to the deculverted stream of $15-30 \%$, which decreases in the farthest buffers to a range of $2.5-5 \%$. Based on these assumptions, together all the plots considered receiving a land value increase that range between USD 282,414,017-564,828,034 (Table 6).

The second step to calculate the land value increase, due to public space creation or to recondition involved nearly $7500 \mathrm{~m}$ of perimeter and around 5600 plots were considered, with a combined area of $1,764,826 \mathrm{~m}^{2}$. The plots were identified in the GIS platform to facilitate the process (Figure 16). Following the same rationale established above, categories based on the distance from the new public spaces were: First line; up to $100 \mathrm{~m}$; and between $100 \mathrm{~m}$ and $200 \mathrm{~m}$ ). In this case, the area estimated was smaller, as this kind of improvement is, in general, considered to have a lesser degree of valorization. To calculate the construction capacity of each category, the plot areas were multiplied by the corresponding maximum FAR allowed by current planning law (summarized in per-category-average values ranging between 1.34 and 1.55). Thus, a combined maximum GFA of 2,310,307 $\mathrm{m}^{2}$ would be possible (Table 7).

Table 7. Valorization on plots affected by public space works.

\begin{tabular}{cccccccc}
\hline $\begin{array}{c}\text { Public } \\
\text { Space } \\
\text { Works }\end{array}$ & Quantity & Area $\left.\mathbf{( m}^{\mathbf{2}}\right)$ & $\begin{array}{c}\text { Average } \\
\text { Max FAR }\end{array}$ & $\begin{array}{c}\text { GFA Max } \\
\mathbf{( m}^{\mathbf{2}} \mathbf{m}\end{array}$ & $\begin{array}{c}\text { Average } \\
\text { Land } \\
\text { Value } \\
\left(\mathbf{U S D} / \mathbf{m}^{2}\right)\end{array}$ & $\begin{array}{c}\text { Valorization } \\
\text { Range (\%) }\end{array}$ & $\begin{array}{c}\text { Valorization Range } \\
\text { (USD) }\end{array}$ \\
\hline $\begin{array}{c}\text { First line } \\
\text { plots }\end{array}$ & 826 & 323,993 & 1.55 & 431,519 & 442 & $7.5-15 \%$ & $14,300,910-28,601,819$ \\
\hline $\begin{array}{c}\text { Plots up to } \\
100 \mathrm{~m}\end{array}$ & 1639 & 470,456 & 1.40 & 629,090 & 472 & $5-10 \%$ & $15,175,518-30,351,037$ \\
\hline $\begin{array}{c}\text { Plots } \\
\text { between } \\
100 \mathrm{~m} \text { and } \\
200 \mathrm{~m}\end{array}$ & 3178 & 970,377 & 1.34 & $1,249,698$ & 413 & $2.5-5 \%$ & $13,979,940-27,959,881$ \\
\hline Total & $\mathbf{5 6 4 3}$ & $\mathbf{1 , 7 6 4 , 8 2 6}$ & & & & & \\
\hline
\end{tabular}

The total land value increase was calculated with the same assumptions adopted in the deculverting case. The per buildable square meter land value was calculated by associating each plot of the study area, obtaining per-category-average values ranging between 413 and $472 \mathrm{USD} / \mathrm{m}^{2}$. The valorization was considered to be directly proportional to the proximity of parks. Thus, it varies according to the group of plots between a maximum range for the nearest buffer of $7.5-15 \%$, which decreases to a range of $2.5-5 \%$-also lower than in the deculverting work, using the same rationale explained above. Together, all the plots experience a land value increase ranging between USD 43,456,368 — 86,912,737 (Table 7). 
The three land valorization conditions studied -1) flood mitigation, 2) creation of a new type of public space with the deculverting, and 3) new or improved public spaces - are combined according to the characteristics of the two scenarios proposed, producing an initial calculation of the total land value increase estimated in each scenario (Table 8). This is expected to be refined in future research, but in the meantime it provides a helpful order of magnitude of potential valorization.

- For Scenario 1, valorization is determined only by flood reduction and is equal to USD 192,453,576.

- In Scenario 2, BGI works add on top of the flood mitigation benefit the valorization, due to deculverting the Medrano channel (in a range between USD 282,414,017-564,828,034) and for the new or recreated public spaces (USD 43,456,368-86,912,737), reaching an expected land value increase ranging between USD 518,323,961-844,194,346.

Table 8. Valorization in each Scenario.

\begin{tabular}{ccc}
\hline Works & Scenario 1 (USD) & Scenario 2 (USD) \\
\hline Flood control & $192,453,576$ & $192,453,576$ \\
Deculverting works & & 282,414,017-564,828,034 \\
Public space works & & $43,456,368-86,912,737$ \\
Total & $\mathbf{1 9 2 , 4 5 3 , 5 7 6}$ & $\mathbf{5 1 8 , 3 2 3 , 9 6 1 - 8 4 4 , 1 9 4 , 3 4 6}$ \\
\hline
\end{tabular}

In this article, land-value increase was calculated for those plots that would be positively impacted by the works proposed in the MSB. The maximum building capacity, according to current planning law, was considered for this estimation. However, this does not imply that this maximum building capacity would be immediately used. A study of the expected construction volume per year and the built stock renewal in the area studied, as well as the calculation of the valuation that local governments could recover to help finance the proposed works are subjects for future studies.

\subsection{Politico-Institutional Questions}

The two possible scenarios to address flooding and improve urban-environmental conditions in the MSB have been discussed above in terms of their design viability, as well as some of the possible costs and benefits produced. In this section, the central question relates to the political and institutional conditions that create challenges and opportunities for the implementation of BGI as an integrated management solution for the MSB. Many of these coincide with other contexts, demonstrating the global relevance of generating political support and designing suitable institutional structures to manage nature-based solutions (NbS) in cities where multiple administrations interact across jurisdictions.

\subsubsection{Politico-Institutional Challenges}

Finding an engineering resolution in an urbanized area is difficult. But this is secondary: You can always resolve the problem if there is political agreement. The most difficult thing is consensus.

(Municipal public servant 1)

Moving towards a river basin management approach that focuses on $\mathrm{NbS}$ and not only traditional engineering requires a gigantic step in practice. In addition to the technical challenge of designing and implementing alternative solutions, such a transition also necessitates strong political support. As Thorne et al. [49] found in their study on the adoption of BGI in Portland, US, decision makers need security regarding both BGI biophysical suitability, as well as support from the community and elected officials to confidently adopt BGI in place of grey infrastructure.

However, there are multiple sources that contribute to a lack of political support for a BGI proposal. First, most of the seven public servants interviewed as part of this research identified the challenge of 
operating in multijurisdictional settings with administrations of different political colours. In particular, this generates different priorities and also some obstacles in everyday governance, for example, in facilitating communication between levels of government or in accessing financing in many cases. Second, long term planning is generally a challenge with fluctuations in administrations. As one public servant from the Province of Buenos Aires Government commented, "we don't explore alternatives for the long-term, for 20 years, for example, ... because in 10 years the government has changed three times. We do not have a State setting stable criteria together. It is very difficult." A third challenge to generating political prioritisation of BGI solutions is a path dependency on two external structuring conditions: The framework of loans offered from multilateral development banks and the current model of public works delivery linked with private interests concentrated in a few companies. Other researchers [4] have verified that grey infrastructure is generally favoured because it is the usual and accepted modality, which does not require changes to public or private roles and responsibilities.

The commencing challenge in this regard is how to generate a bipartisan consensus and how to maintain a focus on a long-term sustainable solution despite administrative changes. One way in which political support is generated is from civil society demands [49], especially a change in awareness brought about by natural disasters. In this regard, some public servants interviewed identified the role severe flooding has played in recent years to place water management on the political agenda, generating new instances of dialogue and collaboration between different administrations. Flooding problems have also prompted innovation at the local level to solve specific infrastructure problems with political support, including through BGI solutions in the case setting as these offered faster, micro-solutions compared to waiting for larger drainage works to be funded and built. (e.g., reservoirs or floodable plazas in the ACBA or the Municipality of Vicente Lopez, or the design and implementation of emergency and evacuation plans in the Municipality of San Martín). Some public servants made the point that without an emergency to create a critical tipping point alternative or innovative proposals usually appear only when the traditional options have been exhausted or for some reason are proven unviable. Other possible opportunities for generating support for a BGI approach are explored below (4.3).

Once the political agreement is reached, the next multifaceted challenge relates to establishing a regional level plan with strategic goals for stormwater management and setting up an appropriate corresponding interjurisdictional governance structure for integrated river basin management. Given the incumbencies of each level of government in the case context, the governance structure requires the participation of three levels of government, and at the bottom of the institutional hierarchy, three different municipalities. Not only are multiple levels involved, but different areas within each government play a role in designing and implementing $\mathrm{NbS}$ that often have many miniscule interventions when compared to traditional hard engineering works that cross urban planning, urban design, public works, open space and stormwater management. In this sense, one public servant commented, "the difficult thing about a large BGI proposal is that they are more atomized than traditional proposals: They are more complicated than a single works proposal with single financing" (Public Servant, GPBA). It requires the difficult work of integrating "silos" to avoid duplications and inefficiencies, while also maximising the social, economic and environmental benefits of coordinated work [50]. Overall, integrated work between different levels and areas of government is required which, according to the interviewees, do not have the same level of political support, institutional structures, priorities or budgets in place to collaborate fluidly. For example, the current Basin Committee for the Medrano Stream (CICAM) does not involve three of the relevant municipal governments in technical or management coordination groups. The MRBA is regarded as fragmented in its governance approach generally [51], with other researchers pointing to specific coordination challenges relating to river basin management [52] given the different operational logics and policies of the government in place.

In addition to achieving better coordination between different government actors, there is also a need to link public management with the interests of civil society and the private sector. The current governance structure offered through the CICAM does not encompass multi-stakeholder collaboration. 
In order to move forward with a BGI agenda, the scope of governance is very wide, for example, involving all the actors in the basin who influence the quality and quantity of stormwater, such as landowners, businesses, community organizations, and government agencies.

One of the tasks for coordinated action between stakeholders is the modernisation and standardisation of relevant regulations. This challenge is made up of two issues: First, because of the complexity of the specific institutional and regulatory framework of the local context, and secondly, because of the general difficulty in stipulating standards for BGI. In relation to the first issue, the set of rules and administrative processes for water management is very complex, involving a broad spectrum of public bodies with different approaches and timeframes for processing, financing and implementation. In fact, the consultants hired by the IDB to develop the Urban Drainage Master Plan for the MSB (2019) consider that the current abundance of standards "does not achieve the objective of protection pursued but, on the contrary, results in limited compliance, due to the complexity involved in properly interpreting the set of regulations" [26] (p. 74). In addition to numerous current standards and practices, gaps have been identified as to the possibility of carrying out a comprehensive evaluation of infrastructure projects. For example, some social and environmental variables that are not currently considered in the decision-making process [52], such as sea level rise or changes to extreme rainfall patterns [53]. Again, in this regard, a regional level plan for the metropolitan area is required that encompasses the various integrated aspects of stormwater management.

Secondly, and as Staddon et al. [54] and Tayouga and Gagné [10] identified in global literature reviews, there is an absence of generally accepted design standards for BGI. This is a problem because it requires more work upfront in feasibility studies based on local context [55], it challenges monitoring tasks [56] and overall makes it difficult to demonstrate adequate functionality [57]. This is required at a regional level that traverses different jurisdictions.

Information management is another politico-institutional challenge. First, the lack of collection, systematisation and analysis of the relevant data for design BGI solutions is a challenge to overcome. Interviewees mentioned the lack of data "measurements" (CABA Officer 3) and "available information" (CABA Officer 1), or the fact that "getting the information requires certain times that are incompatible with project timeframes" (CABA Officer 1). The second challenge relates to the limited exchange of information between areas and also levels of government. For example, for a long time, the technical representatives of the municipalities have not participated in the periodic meetings of CICAM, limiting the opportunity for knowledge transfer. Some difficulty was also mentioned in obtaining intergovernmental contacts for consultation and the difficulty of generating fluid communication at the political level when administrations are not aligned. Third, and as Janches et al. discovered in their study on climate change adaptation in the region, "there is little information available to the public ... which is particularly true for residents of informal settlements" [52]. The fourth challenge for information management is the way knowledge is built about performance outcomes: The evaluation criteria adopted is based on grey infrastructure models, which in turn correspond to the established decision-making frameworks, financing model and the dominant practices of the construction industry. This creates discourse and context that tends to silence other alternatives.

All respondents identified that one of the main challenges and for some of them, the main challenge-is the "limited budget" to generate a comprehensive management plan based on a BGI approach. On the one hand, respondents commented that the budget for public salaries is not enough, so they lack staff or the staff lacks adequate training regarding integrated water management through BGI. On the other hand, the budget is often allocated to address "the multiple critical problems" that exist over "planning much in advance" (GPBA official 1). Furthermore, different levels and jurisdictions of government have very different capacities to finance infrastructure, which produces inequalities throughout the region. Finally, there is no requirement for contributions to the existing governance body, the CICAM, and no funding for its operation beyond the current master plan design. Beyond these localised limitations, another funding challenge at the global level is the frequent requirement to demonstrate that a BGI approach would cost the same or result in a minimisation of costs in relation to 
traditional grey infrastructure. However, given that the same criteria are often used, full socio-economic costs and benefits are not examined (e.g., possible reductions in public health costs to do improved water quality and increased access to open space), which limits the attractiveness of BGI solutions.

A widely studied and recognized problem in the context is the socio-spatial segregation and the inequalities that exist in the MRB in levels of development (e.g., References $[51,58])$. Generally, the best development conditions are located in the centre of the city (downstream) where today there is complete coverage of basic infrastructure and households enjoy good quality housing. Towards the periphery of the MRBA and where the river basins originate, conditions worsen with many households experiencing unsatisfied basic needs and poor housing. Local researchers, such as Gutiérrez [59], have shown how environmental problems unequally affect different territories not only because of physical issues, such as topography, but particularly because of the inequality in the level of development, for example, lack of services, waste collection and of stormwater drainage connections. For those interviewed in this investigation, the lack of planning and the vulnerability of informal neighbourhoods with lower-income sectors is a particular challenge not just for financing BGI as mentioned above, but also for designing sustainable BGI solutions. Basically, there is a theoretical possibility to mitigate some of the inequalities in risk faced by flooding and pollution and to balance access to public and recreational space. However, most authorities do not have adequate resources or capacities to address the already great differences in levels of development and close the gap in terms of households basic unmet needs. They are focused on responding to "emergencies" (Municipal official 1) and critical conditions. As one public servant of the Province summed up: ... we have so many problems to solve in the short term that our eyes are fixed there ... it is a very complex situation with many urgent and basic needs.

\subsubsection{Politico-Institutional Opportunities}

Despite the many politico-institutional challenges, opportunities were also uncovered based on current strengths in water management in the region. Foremost, given the public attention and political commitment to resolving flooding problems, progress has been made in allocating more resources to water management since the 2012 and 2013 floods. Financing for feasibility studies has so far been forthcoming from multilateral development banks (including with the recent condition to adopt some BGI approaches), and the National Water Infrastructure Fund collects income from a fuel tax (Law 26,181) to finance some mitigation actions in the MRB and coordinate the interjurisdictional governance body (CICAM). Furthermore, the provincial government and municipal governments have allocated budgets to redressing flooding and other related infrastructure improvements (e.g., sewerage infrastructure expansion), from small amounts for emergency planning to more significant investments in stormwater drainage or retention.

Another benefit of the turn to focus on addressing flooding is the increasing technical competency of public servants in accompanying the necessary modernisation and innovation processes internally. Some of the interviewees reported participating in recent international training programs and conferences, or pursuing local opportunities for further study in the area of BGI. Collaboration agreements have been reached between local authorities in Buenos Aires and Copenhagen for the purpose of knowledge exchange on water management approaches. Many of these incipient trends are promising in terms of accompanying the transition from a dominant grey infrastructure to BGI approach in terms of raising awareness internally about the challenges and solutions at hand. Some of the pilot projects implemented in municipalities within the MSB also support awareness-raising in the community; another necessary factor to build community support for this transition. 


\section{Discussion}

\subsection{Summary of the Hydraulic-Performance and Land-Value Impact Studies}

Summarizing our main research question — to what extent it is possible to efficaciously apply BGI strategies in the dense urban setting of the MSB?-our preliminary comparative analysis indicates that it is indeed possible and that it entails clear environmental, social and economic benefits. The second scenario creates more value for less cost. It also suggests there are challenges to steering a business-as-usual approach towards a more sustainable and integrated approach to managing stormwater, especially relating to political and institutional factors.

Table 9 summarises the four variables examined in both scenarios: (1) While the construction costs in Scenario 1 are approximately USD 441 million, the sum of the construction costs involved in Scenario 2-comprised of grey-infrastructure works (USD 265 million) plus BGI costs (USD 128 million) -results in approximately USD 393 million; (2) Land-value increase in Scenario 2 is between almost three and four and a half times that of Scenario 1; (3) the protection level was fixed in both cases for a 10-year return period of flood events; and (4) the estimate of the untreated runoff discharge conveyed by grey infrastructure is around $40 \%$ less in Scenario 2.

Table 9. Variables studied in Scenarios 1 and 2.

\begin{tabular}{lll}
\hline \multicolumn{1}{c}{ Variables } & \multicolumn{1}{c}{ Scenario 1 } & \multicolumn{1}{c}{ Scenario 2 } \\
\hline 1 Construction Costs & USD 441 million ** & USD 393 million * \\
2 Land-Value Increase & USD 192 million ** & USD 518-844 million * \\
3 Protection Level against Flood Events & 10-year return period & 10-year return period \\
4 Untreated Runoff Discharge & $100 \%$ & 25approx. 60\% \\
\hline
\end{tabular}

${ }^{*}$ Rounded values. ${ }^{* *}$ Rounded values obtained from UDMP-MSB [26]

If the major grey-infrastructure works of Scenario 1 were combined with the major BGI works of Scenario 2-as mentioned in the introduction-a quick estimation reveals that the construction costs would increase by approximately 29\% compared to Scenario 1 (USD 441 million + USD 128 million = USD 569 million). Untreated runoff discharge would be equivalent to that of Scenario 2 . The protection level would be increased significantly to a 20-year return period event, and the additional flood protection is likely to be reflected in the land value; though further studies are needed to estimate to what extent. As argued above, the expanded superposition of both networks, grey infrastructure and BGI, would also take further the redundancy effect [11], augmenting the overall resilience of the system.

Urban river basin improvement works are normally associated with the creation of value as a result of flood protection for inhabitants and their assets, which is partially expressed in increases in land values. In some cases, this valorization acts as an argument to justify public works. BGI or hybrid-based approaches, add new elements of value for the basins in which they are implemented by expanding or producing new natural and public spaces-which adds to the benefits that already exist with grey infrastructure works, without necessarily incurring an increase in the cost of the works.

The ability of governments to recover part of this land value increase could allow financing of BGI works partially or totally, possibly generating incomes higher than the cost of production. The land-value capture instruments available vary between countries, the most common being in the case of the MRBA in particular and Latin America in general, the collection of Betterment Contributions, Property Tax and the implementation of Charges for Building Rights [60]. Another possibility to recover land value increases could be to generate partnerships between the public and private sectors (PPP), or compensation agreements, in which the use of extra FAR would be compensated by the private sector by building BGI works to the city. The valorization created by BGI projects offers an argument to overcome the resistance that many governments of the Global South face in terms of 
adopting projects based in NbS and BGI, as identified, for example, regarding political and institutional conditions or in terms of design uncertainty.

\subsection{BGI Design and Urban Morphology Notes}

This study showed that in order to advance major BGI development, such as the deculverting of a watercourse, it is necessary to undertake large-scale transformations which sometimes involve a change in the rational in which traditional public spaces, such as parks, are conceived. The hydraulic strategy proposed here was primarily based on the performance of four new large-scale open green reservoirs. The design challenge was to envision these parks with a new landscape-infrastructure lens: Places that are not static and constant throughout time, but on the contrary, are changed by the presence of water.

It is expected that changes of this scale in public space would stimulate a change in the surrounding built environment, in terms of land uses and architectural typologies, as well as the aforementioned changes in land value. These changes should be guided by adjustments in planning law and building codes that would aim to direct these transformations to enhance the resilience of the watershed and the wellbeing of its residents.

The type of progressive transformation of the urban fabric led by planning law changes suggested here involves a gradual replacement of one or two-story residential buildings by mixed-use four-story buildings with smaller building footprints. This would increase the Gross Floor Area (GFA) and potentially the population density. Such a change would be aligned with Compact-City principles, but would contradict a conventional approach to risk management in floodplains, which, in general, aims to halt population growth. Risk @is usually calculated as $\mathrm{R}=$ hazard $\mathrm{x}$ exposure $\mathrm{x}$ vulnerability, where hazard is the threating event (flood in this case), including its probability of occurrence; exposure is the humans/values that are present at the site affected, and vulnerability is the lack of resistance to damaging forces [61]. Reducing the footprint of buildings would increase absorbent soil, thus, decreasing flood hazards and vulnerability. However, population growth would increase the level of exposure. Nevertheless, it could be argued that if this change could entail a replacement of residential units at the pedestrian level by other land uses (e.g., retail or commercial), it would decrease the level of exposure and vulnerability, as a significant amount of the fatal accidents that occur in floods take place in ground-floor residential units at night. This would be an opportunity to progressively transform the ground floors into more open, and thus, more resilient, built forms and to favour a move of the residential population above the first floor.

\subsection{Politico-Institutional Pathways Forward}

As indicated in the above summary, a predominantly BGI approach to stormwater management is not only feasible from an engineering perspective, but also offers urban design opportunities, environmental benefits and new possibilities for financing infrastructure. Nevertheless, there are considerable politico-institutional challenges to steering this transformation. As part of the preparation of the proposed UDMP-MSB, the consultants conducted a study of the existing institutional framework and observed that the current management logic of the water basin "is lagging behind other countries, for a variety of reasons," [26] (p. 176) especially of political, historical and economic origin. The specific challenges identified in this research, from the institutional path dependence on traditional grey infrastructure to the challenge of designing a suitable governance structure to coordinate the actions of disparate public authorities coincide with these findings. These challenges related to how to address interjurisdictional coordination and effect collaboration between governmental and non-governmental spheres or how to operate systematically throughout an entire basin region in terms of funding and information management are not just a local problem, but a challenge common to other cities. For example, in many of the case studies presented in the book Urban Sustainability and River Restoration: Green and blue infrastructure [62], the governance model is mentioned as a challenge for the advancement and institutionalisation of BGI. 
For the local context, the current attention given to flooding problems and the incipient responses provide promise to scale-up a BGI approach. There are also examples of more successful interjurisdictional authorities for river basin management in other Argentine regions (e.g., see References $[59,63])$ that have been studied in some detail and provide lessons for strengthening the currently weak institutional and operational arrangement offered by the CICAM. The current political scenario in which the National and Provincial Governments are politically aligned, along with some of the municipalities involved, also provides an opportunity to oil the wheels of governance. Though the challenges are deep and multifaceted, both local and international experiences demonstrate the possibility of developing a functional institutional arrangement for coordinated action that provide some reassurances for upscaling a BGI approach for the MSB.

\subsection{Concluding Remarks}

The innovation of this study is twofold. First, it attempts to estimate ex ante a land value uplift that would result from a deculverting project. Out of the built cases of deculverting around the globe-mostly located in Western Europe, North America and East Asia-there are few works that quantify and report the land-value increase that results from daylighting projects. After an exhaustive literature review, we found only one rigorous case study on the land value produced ex post after the deculverting of Seul's Cheonggyecheon [17] and none that attempts to anticipate the valorization $e x$ ante, as we have aimed to do here. Second, to date, there are few large-scale BGI projects implemented in Latin America, and there are no constructed deculverting projects in this region [15]. Thus, examining thoroughly what it would entail to deculvert a buried stream in Buenos Aires through multiple analytical lenses offers new insights about steering the BAU model of solely grey infrastructure approaches towards a more NbS through BGI in the region. The method is replicable with up-to-date values and new localised empirical data. Our hope is this will put a much needed spotlight on this debate locally, enrich discussion beyond the region with material from a new case study context and contribute to the development of practicable, sustainable solutions locally and in like high-density settings. This study offers preliminary calculations that should be considered initial studies for further hydraulic and land-value modelling analysis.

Our main research question and literature review led us to approach this exploratory study in a comprehensive way, tackling environmental, technical/hydrological, financial and politico-administrative dimensions. The first scenario represents the BAU conventional approach in which the vast majority of the investment is aimed at obtaining a dry landscape. The second one shows a distribution of economic investment that does not aim to make water disappear from urban life, but on the contrary, seeks ways of safely, including the hydrological cycle in the city [64].

The common practice of channelling and burying streams in urban areas has deteriorated their environmental wealth and limited their drainage capacity, and it has increased the frequency of flooding in urban areas, even more so in the context of climate change. Besides the environmental benefits of reopening sealed culverts and softening the limits of bodies of water in cities, these strategies can effectively create open public space in urban contexts.

However, this is not an easy task, especially in dense urban environments where it is difficult to replace impervious for absorbent surfaces on a large scale, among other design constraints that have been discussed here. Furthermore, political support needs to be garnered, and institutional structures require significant reshaping to accommodate such transformations, including the potential to adopt promising land-vale capture mechanisms to finance infrastructure investments and standardise regional criteria for adopting BGI. There are clear indications and a growing academic consensus on the benefits of pursuing this path. This article aims to contribute to understanding pathways to take-up NbS through BGI in Buenos Aires and potentially other high density cities in the Latin American region. 
D.R. and R.A.; Supervision, D.K.; Writing-original draft, D.K., H.H., A.d.C.M. and D.R.; Writing-review and editing, D.K. and H.H. All authors have read and agreed to the published version of the manuscript.

Funding: This research was funded by the Lincoln Institute of Land Policy, Program on Latin America and the Caribbean, grant number L24Q001-LHH091418.

Acknowledgments: We are thankful to Gabriel Olivares for his invaluable contribution in the hydraulic-performance analysis. Our thanks also go to Andrés Juan and Luis Baer for their insightful methodological inputs for the land-value analysis, and to Natalia Felder, Eliana Ghia and Paula Romano for producing most of the figures that illustrate our findings in this article. Finally, we are thankful to the students and tutors of Proyecto Urbano, Cátedra Jaime Grinberg, FADU-UBA, particularly to Roberto Busnelli, Hernán Feldmann and Roberto Cardini.

Conflicts of Interest: The authors declare no conflict of interest. The funders had no role in the design of the study; in the collection, analyses, or interpretation of data; in the writing of the manuscript, or in the decision to publish the results.

\section{References}

1. Castro Fresno, D.; Rodríguez Bayón, J.; Rodríguez Hernández, J.; Ballester Muñoz, F. Sistemas urbanos de drenaje sostenible (SUDS). Interciencia 2005, 30, 255-260.

2. CIRIA. The SuDS Manual 2015; Construction Industry Research and Information Association (CIRIA): London, UK, 2015.

3. CIWEM. Policy Position Statement on Deculverting of Water Courses; Chartered Institution of Water \& Environmental Management: London, UK, 2007.

4. Dhakal, K.P.; Chevalier, L.R. Urban Stormwater Governance: The Need for a Paradigm Shift. Environ. Manag. 2016, 57, 1112-1124. [CrossRef] [PubMed]

5. Fleming, G.; Frost, L.; Huntington, S.; Knight, D.; Law, F.; Rickard, C.; Macdougall, K.; Ferguson, A. Learning to Live with Rivers; The Institution of Civil Engineers (ICE): London, UK, 2001.

6. Fletcher, T.D.; Shuster, W.; Hunt, W.F.; Ashley, R.; Butler, D.; Arthur, S.; Trowsdale, S.; Barraud, S.; Semadeni Davies, A.; Bertrand-Krajewski, J.-L.; et al. SUDS, LID, BMPs, WSUD and more-The evolution and application of terminology surrounding urban drainage. Urban Water J. 2015, 12, 525-542. [CrossRef]

7. Burian, S.; Edwards, F. Historical perspectives of urban drainage. In Proceedings of the 9th International Conference on Urban Drainage, American Society of Civil Engineers, Portland, OR, USA, 8-13 September 2002.

8. Lamond, J.; Everett, G. Sustainable Blue-Green Infrastructure: A Social Practice Approach to Understanding Community Preferences and Stewardship. Landsc. Urban Plan. 2019, 191. [CrossRef]

9. Vimal, R.; Mathevet, R.; Michel, L. Entre expertises et jeux d'acteurs: La trame verte et bleue du Grenelle de l'environnement. Nat. Sci. Soc. 2012, 20,415-424. [CrossRef]

10. Tayouga, S.J.; Sara, A.; Gagné, S.A. The Socio-Ecological Factors that Influence the Adoption of Green Infrastructure. Sustainability 2016, 8, 1277. [CrossRef]

11. Maruyama, H. Taxonomy and General Strategies for Resilience. In Urban Resilience; Yamagata, Y., Maruyama, H., Eds.; Springer International Publishing: Cham, Switzerland, 2016; pp. 3-21. [CrossRef]

12. Victorian Stormwater Committee. Urban Stormwater: Best Practice Environmental Management Guidelines; CSIRO: Melbourne, Australia, 1999.

13. D'Arcy, B.J. A new Scottish approach to urban drainage in the developments at Dunfermline. In Proceedings of the Standing Conference on Stormwater Source Control, Coventry, UK; Available online: https://scholar.google.com/scholar?hl=en\&as_sdt=0\%2C5\&q=D $\backslash \mathrm{T} 1 \backslash$ textquoterightArcy $\% 2 \mathrm{C}+$ B.J. + A + new + Scottish + approach + to + urban + drainage + in + the + developments + at + Dunfermline. + In + Proceedings + of + the + Standing + Conference + on + Stormwater+Source+Control\&btnG $=($ accessed on 31 December 2019).

14. Wild, T.C.; Bernet, J.F.; Westling, E.L.; Lerner, D.N. Deculverting: Reviewing the evidence on the 'daylighting' and restoration of culverted rivers: Deculverting: Reviewing the evidence. Water Environ. J. 2011, 25, 412-421. [CrossRef]

15. Wild, T.C.; Dempsey, N.; Broadhead, A.T. Volunteered information on nature-based solutions—Dredging for data on deculverting. Urban For. Urban Green. 2019, 40, 254-263. [CrossRef]

16. Lee, M.; Jung, I. Assessment of an urban stream restoration project by cost-benefit analysis: The case of Cheonggyecheon stream in Seoul, South Korea. KSCE J. Civil Eng. 2016, 20, 152-162. [CrossRef] 
17. Kang, C.D.; Cervero, R. From Elevated Freeway to Urban Greenway: Land Value Impacts of the CGC Project in Seoul, Korea. Urban Stud. 2009, 46, 2771-2794. [CrossRef]

18. Kensinger, N. Daylighting the Saw Mill River. Efforts to Bring Back a Natural Yonkers Waterway are Changing the City; Curbed NY: New York, NY, USA, 2016.

19. Schaefer, C. Bishan-Ang Mo Kio Park: From Concrete Canal to Natural Wonderland; MIT: Cambridge, MA, USA, 2014.

20. Jenks, M.; Burton, E.; Williams, K. (Eds.) The Compact City: A Sustainable Urban Form; E \& FN Spon: London, UK, 1996.

21. Urban Task Force. Towards and Urban Renaissance; E \& FN Spon: London, UK, 1999.

22. Williams, K.; Burton, E.; Jenks, M. (Eds.) Achieving Sustainable Urban Form; E \& FN Spon: London, UK, 2000.

23. Jenks, M.; Burgess, R. Compact Cities: Sustainable Urban Forms for Developing Countries; E \& FN Spon: London, UK, 2000.

24. Jenks, M.; Dempsey, N. (Eds.) Future Forms and Design for Sustainable Cities; Architectural Press: Oxford, UK, 2005.

25. Jenks, M.; Kozak, D.; Takkanon, P. (Eds.) 'World Cities' and Urban Form: Fragmented, Polycentric, Sustainable; Routledge: London, UK, 2008.

26. CH2M Hill. Plan Maestro de Drenaje Urbano de la Cuenca del Arroyo Medrano (PMDU CAM); CH2M Hill.: Buenos Aires, Argentina, 2019.

27. Durance, P.; Godet, M. Scenario building: Uses and abuses. Technol. Forecast. Soc. Chang. 2010, 77, 1488-1492. [CrossRef]

28. Godet, M.; Durance, P. Strategic Foresight: For Corporate and Regional Development; UNESCO: Paris, France, 2011.

29. Subsecretaría de Urbanismo y Vivienda de la Provincia de Buenos Aires. Lineamientos Estratégicos para la Región Metropolitana de Buenos Aires; Dirección Provincial de Ordenamiento Urbano y Territorial: La Plata, Argentina, 2007.

30. Chakraborty, A.; McMillan, A. Scenario Planning for Urban Planners: Toward a Practitioner's Guide. J. Am. Plan. Assoc. 2015, 81, 18-29. [CrossRef]

31. Baer, L.; Cuenya, B.; Duarte, J.; Esteban, A.; Itzcovich, P.; Reese, E. La captura de plusvalías en Argentina. In Expandiendo el Uso de la Valorización del Suelo: La Captura de Plusvalías en América Latina y el Caribe; Blanco, A., Fretes Cibilis, V., Muñoz, A., Eds.; BID: Washington, DC, USA, 2016.

32. GCBA. Plan Director de Ordenamiento Hidráulico Para la CABA (PDOH); GCBA: Buenos Aires, Argentina, 2006.

33. Mathur, A.; Da Cunha, D. Design in the Terrain of Water; Applied Research + Design Publishing with the University of Pennsylvania, School of Design: Philadelphia, PA, USA, 2014.

34. Rijke, J.; van Herk, S.; Zevenbergen, C.; Ashley, R. Room for the River: Delivering integrated river basin management in the Netherlands. Int. J. River Basin Manag. 2012, 10, 369-382. [CrossRef]

35. Smith, G.R. Phytoremediation-by-design: Community-scale landscape systems design for healthy communities. Int. J. Sustain. Dev. World Ecol. 2015, 22, 413-419. [CrossRef]

36. Ruby, M.; Appleton, B. Using landscape plants for phytoremediation. In Low Impact Development Conference 2010: Redefining Water in the City, San Francisco, California, CA, USA, 11-14 April, 2010; Curran Associates, Inc.: New York, NY, USA, 2010.

37. Russo, A.; Speak, A.; Dadea, C.; Fini, A.; Borruso, L.; Ferrini, F.; Zerbe, S. Influence of different ornamental shrubs on the removal of heavy metals in a stormwater bioretention system. Adv. Hortic. Sci. 2019, 33.

38. Fritioff, Å.; Greger, M. Aquatic and terrestrial plant species with potential to remove heavy metals from stormwater. Int. J. Phytoremediation 2003, 5, 211-224. [CrossRef]

39. Zanin, G.; Bortolini, L.; Borin, M. Assessing stormwater nutrient and heavy metal plant uptake in an experimental bioretention pond. Land 2018, 7, 150. [CrossRef]

40. Daniel, V.E.; Florax, R.J.; Rietveld, P. Flooding risk and housing values: An economic assessment of environmental hazard. Ecol. Econ. 2009, 69, 355-365. [CrossRef]

41. Soule, D.M.; Vaughan, C.M. Flood protection benefits as reflected in property value changes. J. Am. Water Resour. Assoc. 1973, 9, 918-922. [CrossRef]

42. Crompton, J.L. The impact of parks on property values: Empirical evidence from the past two decades in the United States. Manag. Leis. 2005, 10, 203-218. [CrossRef]

43. Geoghegan, J. The value of open spaces in residential land use. Land Use Policy 2002, 19, 91-98. [CrossRef] 
44. Jim, C.Y.; Chen, W.Y. External effects of neighbourhood parks and landscape elements on high-rise residential value. Land Use Policy 2010, 27, 662-670. [CrossRef]

45. Reporte Inmobiliario. Mapa de Relevamiento de Precios de Inmuebles en la Region Metropolitana de Buenos Aires, Septiembre. 2019. Available online: https://www.reporteinmobiliario.com/miembros/mapas (accessed on 5 September 2019).

46. Jaramillo, S. Hacia Una Teoría de la Renta del Suelo Urbano; Universidad de los Andes: Bogotá, Colombia, 2009.

47. Terraza, H.; Pons, B.; Soulier, M.; Juan, A. Gestión Urbana, Asociaciones Público-Privadas y Captación de Plusvalías: El Caso de la Recuperación del Frente Costero del río Paraná en la Ciudad de Rosario, Argentina. Banco Interamericano de Desarrollo (IDB). 2015. Available online: https://publications.iadb.org/es/publicacion/13875/gestion-urbana-asociaciones-publico-privadasy-captacion-de-plusvalias-el-caso-de (accessed on 10 October 2019).

48. Borrero Ochoa, O. Avalúo de Inmuebles y Garantías; Bhandar: Bogotá, Colombia, 2008.

49. Thorne, C.; Lawson, E.; Ozawa, C.; Hamlin, S.; Smith, L. Uncertainties and barriers to adoption of BGI. J. Flood Risk Manag. 2018, 11, 960-972. [CrossRef]

50. Healey, P. Territory, integration and spatial planning. In Territory, Identity and Spatial Planning; M. Tewdwr-Jones, M., Allmendinger, P., Eds.; Routledge: London, UK, 2006; pp. 88-104.

51. Pírez, P. Para (re)pensar la gestión metropolitana. Territ. Metrop. 2007, 1.

52. Janches, F.; Henderson, H.; MacColman, L. Riesgo Urbano y Adaptación al Cambio Climático en la Cuenca del Río Reconquista en Argentina; Working Paper; Lincoln Institute of Land Policy: Cambridge, MA, USA, 2014; Available online: https://www.lincolninst.edu/es/publications/working-papers/riesgo-urbano-adaptacion-alcambio-climatico-en-la-cuenca-del-rio (accessed on 15 June 2019).

53. Barros, V.; Menendez, A.; Natenzon, C.; Kotot, R.; Codignotto, J.; Bronstein, M.; Camillon, I.; Luduena, S.; Rios, D.; Gonzalez, S.G. 'Storm Surges, Rising Seas and Flood Risks in Metropolitan Buenos Aires'. In Climate Change and Vulnerability; Leary, N., Ed.; Earthscan: London, UK, 2008; pp. 135-151.

54. Staddon, C.; Ward, S.; De Vito, L.; Zuniga-Teran, A.; Gerlak, A.; Schoeman, Y.; Hart, A.; Booth, G. Contributions of green infrastructure to enhancing urban resilience. Environ. Syst. Decis. 2018, 38, 330-338. [CrossRef]

55. Parr, T.B.; Smucker, N.J.; Bentsen, C.N.; Neale, M.W. Potential roles of past, present, and future urbanization characteristics in producing varied stream responses. Freshw. Sci. 2016, 35, 436-443. [CrossRef]

56. Campbell, L.K.; Svendsen, E.S.; Roman, L.A. Knowledge co-production at the research-practice interface: Embedded case studies from urban forestry. Environ. Manag. 2016, 57, 1262-1280. [CrossRef]

57. Kremer, P.; Hamstead, Z.; Haase, D.; McPhearson, T.; Frantzeskaki, N.; Andersson, E.; Kabisch, N.; Larondelle, N.; Rall, E.; Voigt, A.; et al. Key insights for the future of urban ecosystem services research. Ecol. Soc. 2016, 21, 29. [CrossRef]

58. Torres, H. Cambios socioterritoriales en Buenos Aires durante la década de 1990. EURE 2001, 27, 33-56. [CrossRef]

59. Gutiérrez, R.A. Federalismo y políticas ambientales en la Región metropolitana de Buenos Aires, Argentina. EURE 2012, 38, 147-171. [CrossRef]

60. Smolka, M. Implementing Value Capture in Latin America. Policies and Tools for Urban Development; Lincoln Institute of Land Policy: Cambridge, MA, USA, 2013.

61. Kron, W. Keynote lecture: Flood risk= hazard $\times$ exposure $\times$ vulnerability. Flood Defence 2002, 82-97. Available online: http://www.civil.ist.utl.pt/ \{\}joana/DFA-riscos-net/2007-08/kron\%20-\%20flod\%20risk\%20= \%20hazard.pdf (accessed on 10 October 2019).

62. Sabbion, P.; Perini, K. Urban Sustainability and River Restoration: Green and Blue Infrastructure; Wiley-Blackwell: Hoboken, NJ, USA, 2017.

63. Spadoni, E. La regulación de cuencas hídricas en la encrucijada federal. In Construir el Ambiente. Sociedad, Estado y Políticas Ambientales en Argentina; Editorial Teseo: Buenos Aires, Argentina, 2018; pp. 167-216.

64. Stokman, A. Reclaiming urban waters by experiential learning and transformative teaching. In Proceedings of the Segundas Jornadas Ríos Urbanos. Confluencias en el estudio, diseño y gestión de los territorios fluviales, IA-UNSAM/FAU-UNLP/FADU-UBA. Buenos Aires/La, Plata, 8-10 May 2019.

(C) 2020 by the authors. Licensee MDPI, Basel, Switzerland. This article is an open access article distributed under the terms and conditions of the Creative Commons Attribution (CC BY) license (http://creativecommons.org/licenses/by/4.0/). 